\title{
What's so special about born globals, their entrepreneurs or their business model?
}

\author{
Jean-François Hennart ${ }^{1,2,3}$, \\ Antonio Majocchi ${ }^{4}$ and \\ Birgit Hagen ${ }^{5}$
}

\footnotetext{
${ }^{1}$ Department of Management, Tilburg University, Heuvelstraat 14, 5131AP Alphen, Netherlands;

${ }^{2}$ Politecnico di Milano, Milan, Italy; ${ }^{3}$ Aalborg University, Aalborg, Denmark; ${ }^{4}$ Dipartimento di impresa e management, LUISS Guido Carli University, Viale Romania, 32, 00197 Rome, Italy; ${ }^{5}$ Dipartimento di scienze economiche e aziendali, Università di Pavia, Via S. Felice, 7, 27100 Pavia, Italy
}

\section{Correspondence:}

J Hennart, Department of Management, Tilburg University, Heuvelstraat 14, 5131AP Alphen, Netherlands e-mail: j.f.hennart@tilburguniversity.edu
Received: 4 December 2018

Revised: 23 February 2021

Accepted: 7 March 2021

Online publication date: 12 May 2021

\begin{abstract}
There is near unanimity among international business scholars that it takes more time to expand internationally than domestically. Hence, this is why some are puzzled by born globals (BGs), firms that make large foreign sales at birth or shortly afterwards. Explanations given for this "anomaly" are that BGs have exceptional resources-advanced technologies and a high international orientation on the part of their entrepreneurs, and that they rely on cheaper internationalization strategies like the Internet and networks. What is almost completely overlooked is the role of the BG's business model (BM). We analyze the time it took for a sample of Italian SMEs to reach BG status (25\% foreign over total sales) within a three-year time span. Entering both international entrepreneurship (IE) and BM variables, we find that, among the IE variables, a firm's technological intensity, the number of years their founders studied abroad and their foreign language fluency, as well as their use of domestic networks, are statistically insignificant. Variables measuring a firm's focus on a niche $B M$, on the other hand, are statistically significant, along with the international work experience of the founders, with the niche BM explaining a higher level of variance with greater accuracy.

Journal of International Business Studies (2021, corrected publication 2021) 52, 1665-1694.

https://doi.org/ | 0.1057/s4|267-021-00427-0
\end{abstract}

Keywords: born globals; internalization theory; survival analysis; business models; international entrepreneurship; Uppsala model

The online version of this article is available Open Access

\section{INTRODUCTION}

The Uppsala internationalization process model (Johanson \& Vahlne, 1977, 2009) and the export development process literature (e.g., Leonidou \& Katsikeas, 1996) assume that achieving significant sales abroad is more difficult, costly, risky, and time-consuming than doing it at home. This is because selling abroad is thought to require specialized knowledge of each foreign country entered and of how to adapt to it (e.g., Autio, 2017; Andersson, Gabrielsson \& Wictor, 2004; Acs, Morck, Shaver \& Young, 1997) and because that knowledge is assumed to be experiential, i.e., only gained by being physically present there. Consequently, firms are expected to sell first in their home market, which obviously they know well, 
before venturing abroad in a gradual and slow manner (Johanson \& Vahlne, 1977).

For a number of scholars, e.g., Knight and Cavusgil (1996, 2004), McDougall, Oviatt \& Shrader (2003), Weerawardena, Mort, Liesch and Knight (2007), this view is challenged by the existence of firms that sell abroad a significant share of their output at birth or shortly afterwards. Knight and Cavusgil (1996), following Rennie (1993), called them born globals (BGs), and defined them as firms that sell $25 \%$ of their output abroad within 3 years of founding. ${ }^{1}$

The apparent disconnect between the export development process and the Uppsala-inspired views of international expansion as a slow and gradual process, on one hand, and the empirical reality of super-fast internationalizing firms, on the other, has generated a large and growing literature. Almost all of it is in the field of international entrepreneurship, so at the risk of oversimplifying, we will call it the IE stream. In this stream, three main reasons why BG firms deviate from slow internationalization are advanced. First, the development of new transport and communication technologies (e.g., Knight \& Cavusgil, 2004); second, their use of networks (e.g., Coviello, 2006; Coviello \& Munro, 1997; Mort \& Weerawardena, 2006); third, their possession of unique internal resources, specifically high-tech products as well as founders with a global mindset and other favorable personality attributes (e.g., Gerschewski, Rose \& Lindsay, 2015; Knight \& Cavusgil, 2004).

Most conceptual and empirical IE studies have focused on these explanations (Knight \& Liesch, 2016), assuming explicitly or implicitly that the only - or the main - factors that distinguish BGs from non-BGs are internal (Dow, 2017). Yet empirical investigations comparing BGs to non-BGs have uncovered other significant variables, such as a global niche positioning (e.g., Cannone \& Ughetto, 2014; Moen, 2002; Nummela, Saarenketo \& Puumalainen, 2004a; Zucchella, Palamara \& Denicolai, 2007).

We argue that the business model a firm uses is the main factor explaining its internationalization speed. A business model is a holistic description of what a firm sells, how it produces it, delivers it, and to whom, how it captures part of the value created, and how it coordinates and controls its activities (Fjelstad \& Snow, 2018). The approach is wider than that taken by strategy scholars insofar as it considers a firm's complete value network, i.e., its customers, suppliers, partners, and distribution channels. ${ }^{2}$ Hennart (2014) and Osiyevskyy, Troshkova and Bao (2017) have developed conceptual models on how a firm's business model influences the speed of its international expansion. Hennart (2014), for example, demonstrates that firms that have a global niche business model can quickly expand abroad. His predictions are supported by Dow (2017), who found that low transportation costs, a small number of domestic customers, and a focus on unique products and services are significant determinants of the probability a firm will be a BG. Dow (2017), however, did not have the data to compare the explanatory power of these factors with that of traditional IE ones such as founder international experience and reliance on networks, so the relative explanatory power of a firm's business model remains untested. We follow his lead and evaluate simultaneously the explanatory power of traditional IE factors and that of the business model variables suggested by Hennart (2014). Consistent with past studies comparing BGs and non-BGs, we measure internationalization by a firm's ratio of downstream sales to foreign customers over total sales. ${ }^{3}$ In contrast to these studies which have classified firms into BG vs. nonBG and have used that as dependent variable in a logistic regression, we use event history methodology to identify the factors that affect how long it took Italian SMEs to reach 25\% foreign sales within a three- and six-year time window. ${ }^{4}$ The main advantage of event history over logistic regression is that it treats internationalization speed as a continuous variable rather than as a dichotomous one. $^{5}$

Besides being among the first to use event history in this context, this paper is also among the first to empirically test how the characteristics of a firm's business model affect the speed with which it expands abroad. Specifically, we focus on the impact of a global niche business model on internationalization speed, something which "has not been examined extensively in the context of new venture internationalization" (Autio, 2017: 220). We find that firms that have a global niche business model, i.e., that have few competitors and can serve foreign customers through exports without changes in the marketing mix and without having to set up service affiliates abroad, and for which transportation is not a barrier, will achieve significant foreign sales much earlier than those using a mass-market business model. In contrast to the predictions of the IE literature, only one of the traditional IE variables, the length of time founders 
have worked abroad, is consistently statistically significant, while others, such as a firm's technological intensity, its insertion in home networks, the length of time its founders studied abroad and their foreign language fluency, are not. All in all, we show that business model variables are better predictors of a firm's speed of international expansion than the traditional IE variables featured in almost all previous studies. These findings call into question the almost exclusive focus put by the IE literature on BGs on the psychological traits of BG founders, and suggest that a redirection of that literature is overdue.

We first critically review the reasons given in the IE literature for the existence of BGs and show that they are not strongly supported by the relatively small number of empirical studies that have contrasted BGs with non-BGs. We then hypothesize that firms that have a global niche business model will internationalize faster than those with a massmarket one, and test this hypothesis against the more traditional explanations advanced in the IE stream. Next, we describe our Italian sample, explain our methodology, report our results, and finally present our conclusions.

\section{LITERATURE REVIEW}

\section{Firm Internationalization and the Born Global Literature}

Many IB scholars believe that achieving significant sales abroad is generally more difficult, more risky, more costly, and slower than doing the same at home. The point was first made by Hymer (1976), who argued that this was because foreign firms suffered from a liability of foreignness, an assumption "largely unquestioned among researchers working on theories of the multinational enterprise" (Zaheer \& Mosakowski, 1997: 439). The export development process literature has also seen selling abroad as hindered by significant barriers, such as a lack of information on foreign business opportunities, competitive conditions, and potential need for marketing mix adaptations (Bilkey \& Tesar, 1977; Leonidou, 2004). Firms are therefore assumed to see foreign country markets as inherently more risky than domestic ones, avoiding committing resources to foreign sales until they have gained target country experience (Leonidou \& Katsikeas, 1996). A third and highly influential theory, the Uppsala internationalization process model (Johanson \& Vahlne, 1977, 1990, 2009;
Johanson \& Wiedersheim-Paul, 1975; Vahlne \& Johanson, 2017), has also argued that internationalization is a difficult, costly, and slow process. For Johanson and Vahlne (1977), there are significant differences across countries in how to acquire customers, adapt the marketing mix to local conditions, and operate subsidiaries. Consequently, managers need to gather information on a foreign country before committing to it. That information is experiential, in the sense that it requires physical presence in that country. Because of an initial lack of such experiential knowledge, firms are expected to sell in their domestic market first, and then to slowly expand to foreign countries, first to those at low psychic distance, and then progressively to those at higher psychic distance, an assumption that Petersen and Pedersen (1997) have called the "psychic distance postulate". ${ }^{6}$ In short, the liability of foreignness, the Uppsala model, and the export development process literatures have persuaded most IB scholars that firms will be slow at developing foreign sales (e.g., Andersson et al., 2004; Arregle, Naldi, Nordqvist \& Hitt, 2012), and that this will be especially true for SMEs which "have fewer resources and experience compared to their larger counterparts" (Cerrato \& Piva, 2012: 619).

Yet not all firms do behave in that way. In 1993, Rennie described a type of firm, which he called born globals (BGs), behaving in a way that does not fit the pattern predicted by the Uppsala model and export development process theories (see also Knight \& Cavusgil, 1996). ${ }^{7}$ While they predict that only large and well-established firms have enough resources to sell in foreign markets, BGs expand abroad while still young and small, and while they predict that foreign expansion will be gradual and slow and take place only after successful domestic expansion, BGs sell immediately abroad, sometimes even before selling at home. Contrary to the psychic distance postulate, BGs sometimes first expand to countries at high psychic distance (e.g., Bell, 1995; Moen, 2002). Consequently, “... born globals pose an important new challenge to traditional views on the internationalization of the firm" (Knight \& Cavusgil, 2004: 137, cited in Verbeke \& Ciravegna, 2018).

In response to this challenge, IE scholars have advanced three main explanations. The first is that the rise of BGs is associated with a major decrease in international communication and transportation costs. Knight and Cavusgil (2004: 125), for example, note that "widespread diffusion of e-mail, the Internet, and related technologies has made internationalization a more viable and cost-effective 
option". The second explanation is that BGs reduce the costs and risks of internationalization by leveraging networks (e.g., Cavusgil \& Knight, 2015; Coviello, 2006; Coviello \& Munro, 1997; Knight \& Liesch, 2016; Mort \& Weerawardena, 2006; Sharma $\&$ Blomstermo, 2003). The third is that BGs have unique resources that allow them to overcome the usual constraints faced by firms attempting to internationalize. One such unique resource is the high technological intensity of their products. Madsen and Servais (1997: 578) write, for example, that "the growth of a Born Global is positively associated with high innovative skills, including an ability to access effective R\&D" (see also Bell et al., 2003; Moen, 2002; Autio, 2005; Knight \& Cavusgil, 2004). The special abilities and psychological dispositions of founders make up another resource, which has been variously dubbed "learning orientation, entrepreneurial orientation, market orientation, commitment to IB, and a general global orientation" (Knight \& Liesch, 2016: 97) (see also Gerschewski et al., 2015; Jantunen, Nummela, Puumalainen \& Saarenketo, 2008; Kuivalainen, Sundqvist \& Servais, 2007; Moen, 2002; Zhang, Tansuhaj \& McCullough, 2009).

Notwithstanding their popularity, these factors may not be as critical as first thought. First, BGs antedate modern communication and transportation technology. Given (2017: 167), for instance, writes that "Marconi's enterprise seems a fine example of a Born Global almost a century before the term acquired currency. His Wireless Telegraph and Signal Company was international at the moment of its founding ... From its London base, the already multinational enterprise spread further, even faster than the time frame proposed by contemporary definitions of Born Globals". Verbeke and Ciravegna (2018) provide similar examples of pre-WW1 early internationalization by Ford and Siemens. Second, if improved communication and transportation increase the ease with which firms sell abroad, why has this led some, but not all, to be BGs? ${ }^{8}$

Turning to the second explanation, there does not seem to be clear and undisputed empirical evidence that BGs make greater use of networks than non-BGs. Cannone and Ughetto (2014) found that the personal international network of founders was a factor in explaining faster foreign sales, but this finding was not supported by Zucchella et al. (2007), Dib, da Rocha \& Ferreira da Silva (2010), Gerschewski et al. (2015), or Rasmussen, Madsen \& Evangelista (2001).
Are BGs significantly more technologically intensive than non-BGs? Evidence for that is also mixed. True, many BGs are in high-tech sectors such as software and biotechnology, but there are also BGs in low-tech ones, often specializing in high-quality/ high-design products that target narrow international niches (Evers, 2010; Falay, Salimaki, Ainamo \& Gabrielsson, 2010; Evers, 2011). ${ }^{9}$ Dow (2017), whose work we review below, found that high technology was not a differentiating factor between BGs and non-BGs.

Do BG founders exhibit special abilities and psychological dispositions that push them to internationalize their firms faster, as claimed in the IE literature? Empirical studies seem to confirm this, as shown by Jantunen et al. (2008), Knight and Cavusgil (2004), Moen (2002), and Zhang et al. (2009). However, there is a problem. Measures of international orientation - as well as international vision, international entrepreneurial orientation, international marketing orientation, and international entrepreneurial ability - are typically obtained from responses to questionnaires completed by founders ex post, that is after some of them have successfully expanded abroad. Now consider a BG founder who starts a business with no international experience, speaks no foreign languages, and has never thought of selling abroad. Immediately after founding the firm, she is approached by foreign buyers, and as a result ends up exporting all of her production, and this continues for some years, so that the firm becomes a BG. This scenario is not as fanciful as it may seem. In five of the eight BG firms studied by Chandra, Styles and Wilkinson (2009), managers had no knowledge of foreign countries before starting their firm, and their first foreign sale was initiated by foreign buyers - see also Bell (1995) and Crick and Spence (2005). Now let us imagine what the responses of our hypothetical founder would be to the typical survey questions measuring international orientation. She would be asked whether she agrees or disagrees with statements such as "we are able to exploit unexpected opportunities" and "we consistently allocate resources to promising new operational areas" (Jantunen et al. 2008), "our top management is experienced in international business" (Knight \& Cavusgil, 2004), "top management tends to see the world as the firm's marketplace" (Zhang et al., 2009), or whether she has "the vision to be a truly global company" (Gerschewski et al., 2015). One would expect her to agree with all these statements because her success with foreign sales 
has persuaded her that she knew about international business all along, has been able to exploit unexpected opportunities, and has always seen the world as her oyster. In other words, we would expect our founder to take full credit for the successful international performance of the firm, even though it is due mostly to other factors, a behavior consistent with self-serving attributions by which CEOs consistently attribute favorable outcomes to themselves, and unfavorable ones to factors over which they have no control (Bettman \& Weitz, 1983; Miller \& Ross, 1975). However, do her high positive scores actually mean that the firm's high foreign sales are caused by her high degree of global orientation? Or do high levels of foreign sales lead to high global orientation scores in surveys completed after successful internationalization?

A better way of measuring international orientation is by its antecedents. Nummela, Saarenketo \& Puumalainen (2004b) argue that one of them is international experience. Managers who have worked or studied in a foreign country are likely to have accumulated knowledge of that country. Thus, they are more comfortable with the idea of doing business there and tend to see it as less risky, and consequently need less time to commit resources to it (Madsen \& Servais, 1997). Prior knowledge also increases absorptive capacity, so a manager with previous foreign market experience should learn faster how to expand internationally. These two factors can be expected to speed up a firm's international expansion. International experience should, of course, be measured ex ante, that is before the firm has started to sell abroad.

When international orientation is measured through a founder's prior international experience, the results are mixed. Zucchella et al. (2007) found that having worked abroad in similar commercial activities or for an MNE (as well as speaking foreign languages) had a positive influence on export precocity, but international education and personal international experience did not. BG founders in Cannone and Ughetto's (2014) sample were more likely to have studied abroad, but were no better at speaking foreign languages than those of non-BGs. Dib et al. (2010) uncovered no statistically significant difference between BG and non-BG founders in international experience and international education, while in Wickramasekera and Bamberry's (2003) study there were no differences between the two in international work experience and foreign language fluency. Chetty and Campbell Hunt
(2004: 71) found little difference in the international experience of founders of fast and slow internationalizers. In 16 of the 18 private Chinese firms studied by Liu, Xiao and Huang (2008: 498), founders had "no... international experience when their firms internationalized for the first time". Vissak, Zhang and Ukrainski's (2012) study shows that Chinese BG founders had less knowledge of the first foreign market entered than their non-BG counterparts, and were less likely to have worked and studied in that foreign market, a finding consistent with that of Naude (2009). Overall, the relationship between prior international experience and fast internationalization appears to be weaker and more nuanced than advanced in the IE literature.

To sum up, there is mixed support for the main IE explanations for BGs: BGs predate fast air transport, the Internet, and social media; they do not necessarily make greater use of networks; they are not all high-tech; it is impossible to show with responses to surveys administered ex post that BG founders have a particularly high international orientation; and it is unclear whether they start their firm with greater international experience than founders of firms that are slower to internationalize. There must be more to the story.

\section{The Influence of the Firm's Business Model}

It is this disconnect between the main explanations for BGs and the empirical evidence that prompted Hennart (2014) to ask whether internalization/transaction costs theories, theories that predict that firms will sell abroad based on firmspecific advantages (FSAs) (Rugman, 1981; Verbeke, 2009; Verbeke \& Kano, 2015), might provide a more convincing explanation.

Internalization theory predicts that firms compete in foreign markets by internally exploiting their FSAs. However, not all FSAs are the same some are location-bound, and hence non-transferable to foreign countries (Rugman \& Verbeke, 2001). A firm may derive advantages from its control of domestic distribution, or may command a strong domestic reputation, but this will not help it when it expands abroad (Verbeke, 2009). Nonlocation-bound FSAs, such as proprietary technology or unique business models (Verbeke, Coeurderoy \& Matt, 2018) are transferable abroad. While their exploitation in foreign countries can sometimes be achieved without having to access targetcountry resources, this is often not the case, and non-location- bound FSAs must be recombined 
with local resources, such as labor, distribution, raw materials, and utilities (Hennart, 2009; Pitelis \& Verbeke, 2007; Verbeke, 2009; Verbeke \& Kano, 2015). This often entails significant adaptation of the business model to local conditions, and the more location-bound its various elements, the more difficult the transfer (Bohnsack, Ciulli \& Kolk, 2020; Verbeke, 2009). Because local resources are held by local private or public owners, access to them must be arranged, and this takes time, and it also takes time to figure out which adaptations can and must be made to the business model in a given foreign country. Thus, internalization theory has implications for the speed with which a firm can expand its foreign sales: firms with FSAs that can be exploited with little or no recombination with target foreign country resources will rapidly expand abroad, while those with FSAs that require extensive recombination will be slower to internationalize (Verbeke, Zargarzadeh \& Osiyevskyy, 2014). We now develop this theory by further contrasting the FSA configuration of a global niche business model with that of a mass market business model.

What affects the speed at which a firm can expand abroad? Hennart (2014) considers the time needed by a firm to perform the tasks it must undertake to sell its products in foreign countries. The first one is to identify likely customers, educate them, and persuade them to buy. This is quicker if customers seek out and approach a seller than if a seller has to perform those tasks. Having to adapt the marketing mix to each country also takes time, time saved when adaptation is not needed. Closing transactions, the next step, is faster if products are sold under set terms than when they are subject to negotiation. Likewise, having to provide information, training, and repair service close to customers slows down the speed at which a firm can expand foreign sales because it will first have to set up a foreign network of service centers and repair facilities. This is less necessary if the firm sells to repeat and expert customers. ${ }^{10}$ Lastly, products need to be brought to the consumer. If transport is costly and customers are unwilling to pay for it because local substitutes are available, the products will have to be manufactured close to foreign customers. Setting up foreign plants takes time. By contrast, low weight-to-value products and those sold to non-price-conscious customers willing to pay for shipping charges can be exported, a much quicker way to ramp up foreign sales.

Hennart (2014) argues that BGs are quicker at accomplishing all of the tasks listed above. He summarizes his argument in four propositions: BGs are firms that (1) sell niche products and services; (2) sell products and services that do not require country-specific marketing mix adaptations; (3) use low-cost means of communication and delivery; and (4) are based in countries with small home markets for the product or service they sell. The last condition is easy to understand. If a firm intends to serve a select number of globally dispersed customers (say one in a million), being located in a very small market increases the chances that its customers will be foreign (Fan \& Phan, 2007; Knight \& Cavusgil, 2004). ${ }^{11}$

Dow (2017) conducted the first empirical test of Hennart's (2014) propositions. He found support for the predictions that firms with few potential customers in the home market, and with unique products bearing low transportation costs, are more likely to be BGs. He did not, however, enter in the regression the traditional IE variables, such as the prior international experience of founders and their use of networks, and so was unable to determine whether Hennart-type variables have greater explanatory power than traditional IE ones.

\section{HYPOTHESES}

Our goal is to simultaneously test the explanatory power of business model-based explanations of a firm's speed of internationalization with those advanced by the IE literature, i.e., reliance on networks, high technological intensity, and founders with prior international experience. Inspired by Hennart (2014), we hypothesize that firms with a global niche business model will internationalize faster (H1). We then present three hypotheses, H2, $\mathrm{H} 3$, and $\mathrm{H} 4$, which correspond to the main IE explanations for BGs. First we explain why Hennart's (2014) argument is best conceptualized using a business model lens.

\section{Niche Versus Mass-Market Business Models}

While business model scholars diverge in how they define the term, there is clear similarity in their approach (Zott, Amit \& Massa, 2011). A business model reflects the choices a firm has made as to what products and services it wants to produce, to whom it wants to sell them, how they can best be delivered to customers, how to capture part of the customer value, and how to efficiently organize all the required activities (Fjelstad \& Snow, 2018). A business model describes a firm's complete value network, i.e., its customers, suppliers, partners, and distribution channels, as well as the governance 
modes chosen to organize it (Teece, 2010). Business model scholars classify firms by looking at the type of customers they target (e.g., mass market or niche), how they interact with them (e.g., selfservice or personal assistance), which channel they use (owned or independent), and how consumers pay (e.g., one-off or recurrent) (Osterwalder \& Pigneur, 2010). Perhaps more fundamentally, they focus not only on what is produced, but on how value is delivered (Cachon, 2020). They stress the need for coherence between all the building blocks necessary for delivering value, with Massa and Tucci (2013: 423) defining the business model as providing a "systematic and holistic understanding of how an organization orchestrates its system of activities for value creation". A business model can be narrower or broader than an industry. Tesla and General Motors are both automobile assemblers, yet they use very different business models. Likewise, most mobile phone firms have targeted the mass market, but a few have taken a niche approach by focusing on the luxury market (Giachetti, 2018). Some business models, such as the "razor and blade" one, transcend industry boundaries, being used in such diverse industries as coffee (Nespresso), copiers, and aircraft engines (Ritter \& Lettl, 2018). ${ }^{12}$ Given the wide variety of practices followed by firms, a business model approach is helpful, as it can be used to identify groups of firms which behave in distinct ways (Baden-Fuller \& Morgan, 2010; Child, Hsieh, Elbanna, Kamowska, Marinova, Puthusserry, Tsai, Narooz \& Zhang, 2017). In our case, we contrast two generic business models, a mass market business model and a niche business model. ${ }^{13}$

Early applications of the business model approach were purely domestic with most of the early literature focusing on identifying different types of e-business models, but the concept is now increasingly used in international business research (e.g., Asemokha, Musona, Torkelli \& Saarenketo, 2019; Child et al., 2017; Guercini \& Milanesi, 2017; Ojala \& Tyrväinen, 2006; Onetti, Zucchella, Jones and McDougall-Covin, 2012; Osiyevskyy et al., 2017; Rask, 2014; Ciravegna, Kuivalainen, Kundu, \& Lopez, 2018; Bohnsack et al., 2020). As we show below, a business model approach is particularly useful in describing the generic factors that allow some firms to internationalize faster than others.

Table 1 contrasts the internationalization speed of a global niche and a mass market business model. This typology is a Weberian ideal type, derived from conceptual work and used to help in the construction of our hypotheses (Baden-Fuller \& Morgan, 2010). The differences between the two business models described in Table 1 should therefore be seen as a matter of degree. For instance, while there are few purely undifferentiated products, we argue that the degree of differentiation of mass-market goods is, in general, lower than that of niche products. In the following pages, we show why firms characterized by a mass-market business model take longer to internationalize than those with a global niche business model.

Niche products are distinctive, so they have few direct competitors. Distinctiveness is not only based on technology, but also on design, quality, or provenance (e.g., Dalgic \& Leeuw, 1994; Toften $\&$ Hamervoll, 2010; Hagen \& Zucchella, 2014; Falay et al., 2015). As a result, niche sellers enjoy some degree of market power (Merrilees \& Tiessen, 1999). Because they focus on satisfying a highly specific need or taste, or on solving a particular problem, global niche firms target small pockets of market segments (Dalgic \& Leeuw, 1994; Dib et al., 2010; Kotler, 2003; Zucchella, Hagen, Denicolai \& Masucci, 2016). For instance, Interna Contract, an Italian firm that provides the complete décor (furniture, fixtures, and equipment) for hotels and restaurants, specializes in outfitting top-of-the range establishments (five and six-star hotels) worldwide (Bortoluzzi \& Tracogna, 2013). As argued above, only a fraction of niche customers is likely to be domestic, the rest being spread across many countries. ${ }^{14}$ It makes sense for a niche firm to try to capture as many customers as quickly as possible, both to reach the break-even point and to avoid imitation. As niche products address specific needs and tastes, they tend to be bought by consumers who have accumulated specific knowledge and/or experience. That knowledge and experience leads to homogeneous and universal (i.e., non-country specific) preferences and requirements (Fan \& Phan, 2007). The commonality in tastes, as well as the small numbers involved, facilitate communication, and so niche buyers are often members of communities of experts and aficionados who share their experience within the group (Hagen \& Zucchella, 2014; Sullivan Mort, Weerawardena \& Liesch, 2012). As a result, it is quite common for niche buyers to take the initiative and to contact sellers (Chandra et al., 2009), saving the latter the time needed to identify customers and persuade them to buy. Since they are knowledgeable about the product, niche buyers require less persuasion to buy and less after-sales education and 
service than those of mass-market products. Sellers of niche products can therefore expand international sales quickly because they do not have to do market research on a country-by-country basis and subsequently stimulate demand with push or pull campaigns. ${ }^{15}$ Because their buyers have tastes and use conditions which are not country-specific, niche products can be sold worldwide with limited country-specific marketing mix adaptations, which is a huge time-saver (Hagen \& Zucchella, 2014). Niche products are distinctive - that is, they do not have close substitutes - hence their demand curve is likely to be price-inelastic. This makes buyers willing to absorb shipping costs, and sellers therefore able to serve them through exports. Exports make it possible to scale up foreign sales much faster than if one has to set up plants close to customers in foreign locations because the latter requires extensive recombination with foreign country-based resources.

Interna Contract, the design company mentioned earlier, is an example of a B2B born global with a global niche business model. Its first project was the Hyatt Regency hotel in Belgrade, soon followed by other luxury hotels in Germany, Italy, Morocco, France, and Japan (Interna, 2020). Interna now outfits top-of-the-range luxury hotels all over the world (Mazucca, 2006). By drawing on the design flair and craftsmanship of small Italian subcontractors, Interna has been able to offer top quality and design, extreme attention to detail, but also flexibility and timeliness (Messati, 2006). While there are about ten firms providing similar services worldwide, none of them have the competencies to compete in its top luxury niche (Bortolozzi \& Tracogna, 2013). Interna is an Italian firm, but its niche is global, and must be, as few super-luxury hotels open in any given country and year - hence the need to sell globally right from the start. Interna partners with internationally renowned designers like Graves, Putman, Hosohe, and Wettstein. Along with the prestige of the hotels they outfit, their association generates free media coverage in trade magazines, and this was initially very helpful in building their reputation. ${ }^{16}$ Such collaborations also result in positive word-ofmouth promotion, an effective and inexpensive way of reaching potential customers.

Contrast this with firms with a mass-market business model. Such firms sell undifferentiated or slightly differentiated products targeted at a large number of customers. They compete with other firms making similar products. As a result, the demand curve for their products tends to be priceelastic. Because their offering is not unique, they need to spend more time identifying which customers are likely to be interested in their specific product, and what it takes to persuade them to buy. In contrast to buyers of niche products who are looking for a specific product or a solution to a particular problem, those of mass market products need to be motivated to buy a particular brand. Tastes and use conditions for mass-market products also tend to vary across countries, so the marketing mix often needs to be adapted to each country where the firm wants to sell - a key assumption of the Uppsala model. Pinpointing what elements of the marketing mix need changing and how to do it takes time, and may require a foreign presence before manufacturing starts, which also takes time. Buyers of mass market products are less likely to be experts, so more time must be devoted to educating them and solving their problems. This will often require setting up service centers and repair facilities in each foreign country, and this takes time. In contrast, buyers of niche products are generally experts who do not need hand-holding. Lastly, given the large number of customers of massmarket products present in any particular country and their low elasticity of demand, serving them will typically require setting up production facilities close to where they live, an expensive and timeconsuming proposition. Exporting from the home base is generally not a feasible solution for mass market products because buyers of such products are likely to hesitate to absorb shipping costs given the availability of local substitutes, but a lack of exact substitutes makes this possible for niche products.

The net result is that firms that have a niche business model are likely to expand their foreign sales much more rapidly than those that have a mass market business model. This leads us to our first hypothesis:

Hypothesis 1: Firms with a global niche business model internationalize faster than those with a mass-market business model.

\section{The International Entrepreneurship View}

To be able to evaluate the explanatory power of a firm's business model, we contrast that explanation with the three main reasons for BGs advanced in the IE literature, that they rely on networks (H2), that they are high-tech (H3), and that their founders are internationally experienced (H4). ${ }^{17}$ 
The first explanation advanced by IE scholars is that BGs make greater use of networks than other types of firms. In the retrospective to their seminal 2004 article, Cavusgil and Knight (2015: 8) write that "early and rapid internationalization is thought to benefit enormously from network relationships and other forms of social capital". For small and young firms, the firm's network is the network of its founder(s). The foreign ties of founders, both personal and firm-to-firm, are said to provide them with information on foreign opportunities, thereby reducing their perceived risk of going abroad, and facilitating access to resources (Chandra et al., 2009). Scholars have measured this impact in three ways: first, they have argued that firms that are located close to similar firms at home, i.e., in home-based industrial districts, can benefit from the international knowledge of other individuals and firms located there (Dib et al., 2010; Fernhaber, McDougall-Covin \& Shepherd, 2009; Fernhaber \& Li., 2013; Prashantham, Dhanaraj \& Kumar, 2015). Zucchella et al. (2007) found some support for this. Second, IE scholars have hypothesized that pre-existing international personal and firm-to-firm networks provide BGs with information that helps them internationalize quickly. Loane and Bell (2006: 475) note that a quarter of the BG founders they surveyed "leveraged their own social or business contacts to gain knowledge of and accelerated access to foreign markets". Among the high-tech startups studied by Cannone and Ughetto (2013), those whose founders had a preexisting international network were more likely to be BGs. The role played by prior network relationships in stimulating foreign sales is also noted by Coviello (2006) and Ellis and Pecotich (2001). Consequently, there are reasons to believe that:

Hypothesis 2: The greater a firm's use of preexisting international networks, the faster its internationalization.

The IE literature holds that high technology is a prerequisite for fast internationalization (e.g., Bell et al., 2003; Madsen \& Servais, 1997; Moen, 2002; Rennie, 1993). Knight and Cavusgil (1996: 11) see technological intensity as a fundamental aspect of BGs, and define BGs as "small, technology-oriented companies that operate in international markets from the earliest days of their establishment." Autio (2005:13) considers a firm's knowledge intensity as an "important facilitating condition" for quick international expansion while Bell et al. (2003: 349) posit that "firms with highly sophisticated knowledge bases are likely to internationalize much more rapidly than are those with more basic capabilities." Knight and Cavusgil (2004: 128) explain that this is because technological innovations "help firms to attenuate their liabilities of foreignness and newness." Indeed, Autio, Sapienza and Almeida (2000) find that a firm's knowledge intensity is positively correlated with the growth of their foreign sales. Hence,

Hypothesis 3: High-technology firms will internationalize faster than low-technology firms.

A third explanation advanced by IE scholars centers on founder prior international experience (e.g., Chetty \& Campbell-Hunt, 2004; Cannone \& Ughetto, 2014; Dib et al., 2007; Wickramasekera \& Bamberry, 2003; Zucchella et al., 2007). International experience has many dimensions. Johanson and Vahlne (1977) argue that the most relevant is experiential knowledge of the relevant target country. Hence, founders who have spent time in the countries where their firm will operate later are more likely to overcome barriers due to cultural and institutional differences, allowing them to expand foreign sales there faster (Chetty \& Campbell-Hunt, 2004; Madsen \& Servais, 1997). It is also possible that prior work experience in any foreign country equips founders with skills that are useful for entering other foreign countries, and hence that firms led by founders with such experience are more likely to be BGs (Cannone \& Ughetto, 2014). BG founders who have worked for an import-export company or an MNE (not necessarily abroad) may also have learned export skills that might speed the internationalization of their firms (Wickramasekera $\&$ Bamberry, 2003; Zucchella et al. 2007). ${ }^{18}$ Perhaps less directly relevant, but still significant, is having studied abroad prior to starting a firm (Dib et al., 2010). Madsen and Servais (1997) and Zucchella et al. (2007), among others, have also argued that founders who speak foreign languages are more likely to be fast internationalizers.

These predictions have been partly supported in studies comparing BGs and non-BGs. Cannone and Ughetto (2014) found that a founder's international work experience and study abroad had a significant impact on their firm's speed of internationalization, Zucchella et al. (2007) found that this was the case for a founder's foreign language 
Table 1 Speed of internationalization for mass-market and niche business models

\begin{tabular}{lll}
\hline & Mass market business model & Niche business model \\
\hline Total number of customers & Many & Few \\
Ratio of domestic to total customers & High & Low \\
Potential competitors & Many & Few \\
Potential product substitutes & Many & Few \\
Price elasticity of demand & High & Low \\
Time needed for customer & Substantial; through advertising and/or sales & Little to none; customer often finds \\
identification & network & seller \\
Time needed for customer & Substantial; need for advertising campaign and/or & Little to none; customer comes ready \\
persuasion & sales networks & to buy \\
Time needed for customer education & Substantial; customer often novice & Little to none; customer often expert \\
Time needed for country-specific & Substantial & Little to none; country-based \\
marketing mix adaptation & & adaptation usually minor or zero \\
Time needed to set up after-sales & Substantial; generally needs to be close to customer & Little to none; can be done from home \\
service & & base if needed \\
Time needed to set up logistics & Substantial: need to locate production close to & Little; home production can be scaled \\
& customer due to price-elastic demand & up quickly and exported \\
\hline
\end{tabular}

fluency, while in Wickramasekara and Bamberry (2003) firms with founders who had worked previously in import-export were also faster to internationalize. Hence:

Hypothesis 4: Firms led by entrepreneurs with greater prior international experience will internationalize faster. This will be the case if they have previously

H4a: spent time in the countries where their firm will later operate;

H4b: worked abroad;

H4c: studied abroad;

H4d: worked for firms active in import-export;

H4e: worked in MNEs;

H4f: acquired knowledge of foreign languages.

\section{METHODOLOGY AND SAMPLE}

Our empirical setting is Italy, an open economy with global companies, many of them SMEs, and hence a good context to investigate speed of international expansion (e.g., Zucchella et al., 2007). Since some of our variables are about initial conditions, we targeted relatively young firms to reduce potential retrospective bias. To avoid potential industry bias, the firms are in many different industries. We randomly selected 1000 Italian firms founded around the year 2000, which were not subsidiaries of other firms, and obtained their e-mail addresses from the official register of Italian companies compiled by Unioncamere, the Association of Italian Chambers of Commerce. We submitted a draft of our questionnaire to experts in
SME internationalization and pretested it with five managers so as to guarantee its comprehensiveness and clarity. Data were collected between October 2014 and February 2015 using an Italian language web-based survey.

The survey included an outline of the goal of the research, introduced the scholars conducting it and their university affiliations, and assured anonymity. It was directed at founders or senior managers who have been with the company since its foundation. As the firms selected are young, and hence the events recent, we are confident that the respondents had the knowledge to answer the questions. After two reminders, we had received 295 responses. After eliminating questionnaires with missing values, we ended up with 222 observations, a response rate of $22.2 \%$. Following Armstrong and Overton (1977), we tested for nonresponse bias by comparing the size, age, propensity to sell abroad, and foreign sales intensity of early and late respondents. There were no significant differences between the two groups.

As we obtained data for both our dependent and main independent variables from the same respondent, we potentially run the risk of common method variance (Chang, van Witteloostuijn \& Eden, 2010). Common method variance arises when respondents provide answers to survey questions that fit their mental models but are not necessarily true. This is more likely to occur when the data collected are subjective, when survey questions on the dependent and independent variables follow each other, and when some answers are seen as more socially acceptable than 
others. In the case of our study, both the dependent variable (time to reaching $25 \%$ foreign sales) and the independent variables (e.g., location of potential customers, modes of transportation used, number of years spent working in an import-export firm) are factual, and hence the responses are not likely to be affected by social desirability. To reduce the risk of creating mental models that link a founder's international experience to his/her firm's foreign sales volume, we put questions on the firm's business model between those on level of exports and entrepreneurial team international experience. Some explanatory variables (regional export intensity and industrial district membership) were also collected from secondary sources. We cross-checked survey responses on the firm's year of foundation and B2C status with those datasets. For all these reasons, we are confident that our study does not suffer from common method bias.

Table 2 gives some information on the firms in our sample. Thirty-eight of them (17.1\%) were BGs, as they had attained $25 \%$ foreign sales intensity within three years of start of business. BGs were on average larger (92.71 employees vs. 50.28 for nonBG), had a higher foreign sales ratio ( 66.10 vs. 15.72 for non-BG), and were less likely to sell to final consumers (B2C) than to businesses (B2B): $45 \%$ of BGs sold to final consumers (B2C), vs. $66 \%$ of nonBGs. In Table 3 we present descriptive statistics for the main variables.

\section{Methodology}

BGs are firms that internationalize fast. The IE literature has typically sorted firms into two categories, those that reach a high percentage of foreign sales (typically 25\%) in a short amount of time (generally three years), i.e., BGs, and those that do not, non-BGs. A logit or probit regression is then used to identify which factors determine whether a firm will fall into one category or the other (e.g., Cannone \& Ughetto, 2014; Dib et al., 2010). One limitation of this approach is that the criteria used to determine whether a firm is a BG or not are somewhat arbitrary, and indeed researchers have used different standards (Gerschewski et al., 2015; Kuivalainen Saarenketo \& Puumalainen, 2012). Another limitation is that dichotomous categories are a rough approximation for what we really want to analyze, which is the speed taken by a firm to reach a particular internationalization benchmark, a continuous variable. A BG/non-BG dichotomous variable makes for a crude measure of speed, since both a firm with zero foreign sales and one that falls just short of the foreign sales intensity benchmark are classified as non-BG, while their internationalization speed is obviously quite different. The time needed to reach $25 \%$ foreign sales is thus a finergrained measure of our dependent variable.

The most useful method for analyzing the speed with which a firm reaches a particular benchmark is event history analysis (Allison, 1984), which explores the determinants of the time to an event within a given observation window. This method has been widely used in IB research (e.g., Hennart, Kim \& Zeng, 1998; Mata \& Portugal, 2000; Sui \& Baum, 2014) but not, as far as we know, in the BG literature. In our case, the event is the firm having foreign sales equal or larger than $25 \%$ of total turnover within three years. We use a Cox proportional hazards model (Cox, 1992) because it makes no specific assumption as to the underlying distribution of the probability of event occurrence. In further analyses, we also use the more conventional logistic model where we predict whether a firm will be a BG or a non-BG based on $25 \%$ foreign sales being reached in three years.

\section{Dependent Variable}

Our dependent variable is the time (measured in months) elapsed between the date at which a firm first puts its product or service on the market and its reaching 25\% foreign sales. We use a three-year observation window in our main models (Models 1 and 2 in Table 5). While there is no universally accepted definition of a BG, 25\% foreign sales in three years is used by most authors (e.g., Cannone \& Ughetto, 2014; Gerschewski et al., 2015; Knight \& Cavusgil, 2004; Kuivalainen et al., 2007). We asked respondents to give the percentage of foreign sales at various time intervals since founding, and from this calculated the number of months a firm took to reach the $25 \%$ export threshold. Firms that did not reach $25 \%$ foreign sales in three years are right-censored.

\section{Explanatory Variables}

\section{Global niche usiness model}

Hypothesis 1 states that firms that follow global niche strategies will be quicker to achieve BG status. Table 1 summarizes the main features of a global niche business model. As argued earlier, niche products are distinctive, and hence have few competitors. They also cater to a limited customer base, hence they have relatively few customers 
(Kotler, 2003). We asked respondents whether they could give us the number of their competitors and clients, or whether the number was too large for them to know. We used a dummy variable coded one if they could not give us the number of competitors (Many Competitors) and clients (Many Clients) and zero if they could. Because global niche products cater to a select number of customers who are similar worldwide, but differ from the average customer in a given country, it is likely that a high proportion lives abroad. To measure this, we asked respondents to estimate the percentage of potential clients located in Italy (Clients in Italy).

Firms selling global niche products can serve foreign markets from a domestic base. This is easier if they do not have to adapt products for foreign customers. We measure this by the variable High Adaptation where we asked respondents to indicate the importance of marketing mix adaptation for their main product and service on a scale of 0 (no adaptation required) to 100 .

Transportation costs are another potentially relevant factor. However, it is not the absolute level of transportation costs that matters, but its impact on demand. That impact will be negligible if product demand is priceinelastic. In that case, an increase in price due to transportation costs will have little effect on demand, and a product exported with significant transportation costs will still find customers. What we want to measure, therefore, is the sensitivity of demand to transportation costs. To proxy for this, we take the type of transportation used by sellers. We assume that if they ship by plane, it is because customers are willing to absorb the charges because the product is distinctive and has no local substitutes. The other case where transportation costs do not hamper exports is when transportation is costless, as with electronic transfer. Altogether, if transportation costs are zero or if demand is price inelastic, transportation charges will not reduce demand. Consequently, sellers with products shipped by air or transferred electronically should find it easier to quickly increase foreign sales compared to those that rely on boats, trains, or trucks. We asked whether respondents delivered their products to customers by train, truck, ship, air, electronic transfer, and in person (door-to-door). Our measure of the sensitivity of demand to transportation costs, Sensitivity to Transportation Costs, is the percentage of sales delivered by truck, train, and ship.

Having to set up a physical presence abroad to handle after sales is also likely to slow down internationalization. We assessed the need for a local physical presence to serve customers by asking respondents to rank the importance of providing repair and after-sales service close to the consumer (High After Sales Service), from 0, not important, to 100 , very important.

One would expect systematic differences in internationalization speed between firms that sell to other firms (B2B) and those that sell to final consumers (B2C) (Andersson, 2006). B2B firms have fewer customers with better knowledge of the product and more homogeneous preferences across countries (Schilke, Reimann \& Thomas, 2009). In contrast, B2C firms have a larger number of customers who need to be persuaded through country-specific advertising and whose demand is more influenced by national culture, thus requiring a more country-by-country marketing mix adaptation. However, the match between $\mathrm{B} 2 \mathrm{~B}$ and niche strategies, and B2C and mass market strategies, is far from perfect, as some $\mathrm{B} 2 \mathrm{C}$ firms have a niche business model, and some firms selling B2B a massmarket one. In our survey, we asked respondents whether they mostly sold B2B or B2C and created a dummy variable $(B 2 C=1)$ when their business was mostly B2C.

To facilitate interpretation and to save on degrees of freedom, we built a formative scale with all the business model variables that negatively affect internationalization speed (Many Competitors, Many Clients, Clients in Italy, High Adaptation, Sensitivity to Transportation Costs, High After Sales Service and B2C). Following Reuber and Fischer (1997), we transformed these variables into $\mathrm{z}$-values. We took their sum, reversed the sign so that the scale has a positive impact on internationalization speed, and called it Niche BM Index. Firms with a high Niche BM Index are more likely to be BGs. Table 2 shows that the average value of the Niche BM Index for the BGs in the sample is 1.94 vs. -.40 for the non-BGs, a statistically significant difference $(p<0.000)$.

\section{International entrepreneurship variables}

We also entered the three main IE variables, a firm's use of networks (H2), its high level of technology (H3), and its founders' previous international experiences and linguistic ability ( $\mathrm{H} 4)$.

$\mathrm{H} 2$ posits that using pre-existing networks speeds up foreign sales. The IE literature has defined networks as (a) the personal relationships of the entrepreneurial team with foreign individuals (e.g., Dib et al. 2010; Ellis, 2011); (b) the business relationships of the firm with foreign firms (e.g., Al-Laham \& Souitaris, 2008; Dib et al., 2010; Yu 
et al., 2011); (c) the relationships gained by being located close to similar firms (e.g., Dib et al., 2010; Fernhaber \& Li, 2013; Fernhaber et al. 2009; Zucchella et al. 2007). In the case of very small firms, like those in our sample, the preexisting international contacts of the firm are those of its entrepreneurial team. Research has shown that the most useful contacts for further internationalization are those made in previous foreign employment (e.g., Crick \& Spence, 2005; Ellis \& Pecotich, 2001; Loane \& Bell, 2006). Since we are already measuring an entrepreneurial team's previous work experience, and hence are implicitly taking into account the team's preexisting international networks, we focus on (c), whether internationalization was facilitated by being located near other firms. Brown and Bell (2001), for example, note that firms in clusters Silicon Valley or Italian industrial districts - help each other internationalize by exchanging referrals, sharing experiences, organizing trade fairs, and so on (see also Andersson, Evers \& Griot, 2013). ${ }^{19}$ We ascertained whether the firm was located in an industrial district that specializes in its type of products, in which case the dummy (Industrial District) is equal to 1 . Data were obtained from the Italian Census of Industry (ISTAT, 2015a).

To test H3, we asked respondents to evaluate their firm's technological level in a range from 0 to 100 (High-Tech). Objective measures of technological intensity (such as R\&D expenditures/sales, or patent counts) are not appropriate for small firms that generally do not have distinct $R \& D$ departments (Love \& Roper, 1999). Patents only measure some types of knowledge, and their usefulness varies across industries making them a poor measure of technological intensity when comparing, as we do, firms across industries. Most scholars therefore agree that in the case of small firms the best way to measure technological intensity is to ask managers for their own assessment, and many past studies have measured this through a single questionnaire item (Dib et al., 2010; Golovko \& Valentini, 2011; Sterlacchini, 1999).
Empirical studies of the impact of experience on entrepreneurial success have shown that the type of foreign experience that is most useful is that which involves solving practical task-related problems overseas in a work environment (Majocchi, D'Angelo, Forlani \& Buck, 2018). This suggests that experience working in countries which are the firm's main markets, or in import-export, or in multinational firms, is likely to have the greatest impact on the probability a firm will be a BG. Guided by this, and based on an exhaustive survey of the various dimensions of international experience used in the IE literature, we entered six measures of prior international experience: (a) the number of years prior to product launching members of the firm's entrepreneurial team had worked or studied in one of the countries which later became their main markets (Years in 3 Main Countries); when there was more than one team member, we took the number of years of the one with the longest foreign experience, because we believe that it is not the average experience of the team that matters, but the presence or absence in the team of a highly experienced individual. ${ }^{20}$ We used the same methodology for other variables describing prior international experience; (b) the number of years members of the entrepreneurial team worked abroad (Years Worked Abroad); (c) the number of years they spent studying abroad (Years Studied Abroad; (d) the number of years they spent working in import-export (Years in Import-Export) and (e) in an MNE (Years Worked in MNE); and (f) the number of foreign languages spoken prior to starting the firm (Foreign Languages).

\section{Control variables}

Cannone and Ughetto (2014), Westhead, Wright and Ucbasaran, (2001), and Verbeke et al. (2014) have argued that a founder's previous experience in the same industry should lead to faster internationalization. We therefore asked respondents how many years they had previously worked in the industry in which their present firm is active (Same

Table 2 Sample characteristics

\begin{tabular}{|c|c|c|c|c|c|c|c|c|}
\hline \multirow[t]{2}{*}{ Variable } & \multicolumn{4}{|c|}{ Non-born global firms: 184 obs } & \multicolumn{4}{|c|}{ Born global firms: 38 obs } \\
\hline & Mean & Std. Dev. & Min & Max & Mean & Std. Dev. & Min & Max \\
\hline Foreign sales ratio 2014 (\%) & 15.72 & 24.31 & 0 & 100 & 66.10 & 23.91 & 0 & 100 \\
\hline Number of employees & 50.28 & 12.93 & 3 & 1078 & 92.71 & 278.59 & 10 & 1700 \\
\hline$\% \mathrm{~B} 2 \mathrm{C}$ & 66 & 47 & 0 & 100 & 45 & 50 & 0 & 100 \\
\hline Niche BM Index & -.40 & 2.72 & -6.42 & 6.21 & 1.94 & 2.51 & -3.35 & 7.01 \\
\hline
\end{tabular}


Table 3 Descriptive statistics

\begin{tabular}{|c|c|c|c|c|c|}
\hline Variable & Mean & Std. Dev. & Min & Max & $\begin{array}{c}\text { VIF } \\
\text { average } 1.22\end{array}$ \\
\hline Many Clients & 0.32 & 0.47 & 0 & 1 & 1.14 \\
\hline Many Competitors & 0.67 & 0.47 & 0 & 1 & 1.18 \\
\hline Clients in Italy & 59.08 & 34.53 & 0 & 100 & 1.14 \\
\hline High Adaptation & 56.59 & 40.81 & 0 & 100 & 1.06 \\
\hline Sensitivity to Transportation Costs & 79.99 & 29.44 & 0 & 100 & 1.15 \\
\hline High After-sales Service & 58.24 & 39.63 & 0 & 100 & 1.15 \\
\hline $\mathrm{B} 2 \mathrm{C}$ & 0.62 & 0.49 & 0 & 1 & 1.19 \\
\hline Niche BM Index & 0.00 & 2.82 & -6.42 & 7.07 & 1.13 \\
\hline Years in 3 Main Countries & 1.10 & 4.85 & 0 & 40 & 1.30 \\
\hline Years Worked Abroad & 0.94 & 3.82 & 0 & 40 & 1.51 \\
\hline Years in Import-Export & 0.76 & 3.79 & 0 & 35 & 1.35 \\
\hline Years Worked in MNE & 1.85 & 5.39 & 0 & 30 & 1.52 \\
\hline Years Studied Abroad & 0.32 & 1.62 & 0 & 20 & 1.22 \\
\hline Foreign Languages & 0.72 & 0.87 & 0 & 4 & 1.17 \\
\hline High-tech & 70.23 & 24.17 & 0 & 100 & 1.15 \\
\hline Industrial District & 0.12 & 0.33 & 0 & 1 & 1.06 \\
\hline Same Sector & 8.69 & 11.46 & 0 & 60 & 1.15 \\
\hline Regional Export Intensity & 0.22 & 0.09 & 0.01 & .37 & 1.14 \\
\hline
\end{tabular}

Sector), again taking the founder with the highest number of years if there were more than one founder.

The level of infrastructure supporting exports varies considerably between northern Italy, with a long industrial tradition, and southern Italy, which has remained heavily agricultural. Most authors studying Italian exports (e.g., D'Angelo, Majocchi \& Buck, 2016) control for the export intensity of the province where the firm is based. Following Bernard and Jensen (2004), we enter its ratio of exports over GDP (Regional Export Intensity) for the year in which the firm started production. ${ }^{21}$ Data were obtained from the Italian National Institute of Statistics (ISTAT, 2015b).

Table 4 shows the correlation between the variables. With the exception of those between Niche $B M$ Index and its constituent variables (Many Clients, Many Competitors, Clients in Italy, High Adaptation, High Transport Costs, High After Sales Service and B2C), which are not of concern since we do not enter them together, the highest correlations are between Years Worked Abroad and Years in 3 Main Countries and between Years Worked in MNE and Years in Import-Export. Table 3 shows that the highest Variable Inflation Factor (VIF) is 1.52 and the average 1.22 , both much below the maximum of 10 set up by Hair, Anderson, Tatham \& William (1995). Hence, we conclude that collinearity is not a problem.

\section{Results}

Table 5 shows the results of the event history models with a 3three-year window. Our dependent variable is the time it took a firm to reach $25 \%$ foreign sales over total sales. A positive coefficient signifies that the variable helps firms attain that level faster, while a negative sign shows that it slows them down.

Model 1 includes our controls, Regional Export Intensity and Same Sector, the global niche business model variables, and the IE variables. In Model 2, we substitute the global niche business model variables with the Niche BM Index. The coefficients and the $p$ values are fairly stable across both specifications in both magnitude and significance: the two models support the same conclusions.

Starting with the controls, the provincial export ratio (Regional Export Intensity) is positive and significant in both models - the highest $p$ value is equal to 0.048 in Model 1 - supporting the view that the regional level of infrastructure has a positive impact on internationalization speed, consistent with Basile, Giunta \& Nugent (2003). In contrast to the findings of Cannone and Ughetto (2014) and Westhead et al. (2001), but in agreement with those of Verbeke et al. (2014), we find that founders who now operate a firm in the same industrial sector as the one in which they were previously active (Same Sector) are not expanding 
their foreign sales faster than those who are new to the industry ( $p$ values are above 0.488 ).

How well did our business model variables do? In Model 1 of Table 5, the coefficients of all our niche business model variables are significant with the exception of the firm's number of total customers at home and abroad (Many Clients). As expected, firms which have many competitors (Many Competitors) take more time to expand foreign sales, as shown by the negative and significant coefficients of this variable ( $p$ value $=0.097)$. Internationalization is also slower the higher the percentage of potential customers who are in Italy, as the coefficient of Clients in Italy is negative and significant with a $p$ value of 0.014 . The negative and significant coefficient of High Adaptation ( $p$ value $=0.033$ ) indicates that firms that make extensive crosscountry adaptations in their marketing mix are less likely to ramp up rapidly their foreign sales. The negative and significant coefficients of Sensitivity to Transport Costs $(p$ value $=0.016)$ tells us that firms that make heavy use of truck, train, and ship transportation (as opposed to using the Internet and the airplane) expand their foreign sales more slowly. Similarly, firms that need to provide their customers with local after-sales service also internationalize more slowly, as shown by the negative and significant coefficient of the High After-Sales Service variable ( $p$ value $=0.008)$. Finally, firms that sell to final customers (i.e., B2C firms) take longer to develop their foreign sales, as the coefficient of $B 2 C$ is significantly negative ( $p$ value $=0.086$ ).

In Model 2, we replace the BMvariables by our Niche $B M$ Index. The coefficient of the index is positive and strongly significant ( $p$ value $=0.000$ ). Altogether, our results support our $\mathrm{H} 1$ hypothesis that firms with a niche business model are faster at internationalizing. This conclusion is supported both when we look at each of the business model variables separately - as in Model 1 - and when we use the Niche BM Index, as the index is statistically significant and so are all the business model variables, with the exception of a firm's number of customers.

Turning to the IE variables, the results for the international experience of the entrepreneurial team are mixed. The longer entrepreneurs have worked abroad, the faster their firms will increase their share of foreign sales: the variable Years Worked Abroad takes a positive and significant sign in all runs with $p$ values of 0.005 in Model 1 and 0.01 in Model 2. Years in Import-Export has a positive sign and is weakly significant in Model $1(p$ value $=$ $0.078)$ but not in Model 2 ( $p$ value $=0.205)$. All other experience variables are insignificant: we do not find support for the existence of a relationship between a firm's speed of internationalization and the work experience of its top managers in the three main countries in which the firm now sells (Years in 3 Main Countries), their prior knowledge of foreign languages (Foreign Languages), the time they spent working in an MNE (Years Worked in MNE) and studying abroad (Years Studied Abroad). Both Cannone and Ughetto (2014) and Wickramasekera and Bamberry (2003) also found foreign language fluency to be statistically insignificant, while study abroad was also found insignificant by Dib et al. (2010), Zucchella et al. (2007), and Vissak et al. (2012). Finally, as with Dib et al. (2010), we found that being located in an industrial district (Industrial District) had no impact on a firm's internationalization speed ( $p$ values higher than 0.486 in both models).

Overall, both models do not provide support for most IE variables. Firms located in industrial districts do not internationalize faster, hence $\mathrm{H} 2$ is not supported. High-technology firms are not more likely to be BGs, so H3 is not supported. With the notable exception of the founders' prior work experience abroad, our other variables measuring the prior foreign experience of the firm's managers, i.e., their previous experience in the firm's main target countries, in firms engaged in international business, in foreign education, as well as their foreign language fluency, do not seem to boost their firm's internationalization speed, hence there is only partial support for $\mathrm{H} 4$.

Figure 1 shows the reversed Kaplan-Meier survival functions for firms with a Niche BM Index above the mean (Niche BM dummy=1), i.e., firms we would expect to internationalize quickly, and for those with a Niche BM Index below the mean (Niche BM dummy $=0$ ), firms that should be slower to reach BG status. The $x$-axis gives the number of months elapsed since the firm started to sell its product, while the $y$-axis indicates the cumulative percentage of firms of each category that reach BG status. Firms with a Niche $B M$ dummy equal to 1 (those we would expect to reach BG status quickly) are represented by a solid line, and those with a Niche BM dummy equal to 0 , our predicted slow internationalizers, by a dotted line. Figure 1 shows that firms with a Niche $B M$ dummy equal to one, our predicted fast internationalizers, do internationalize faster.

How does the explanatory power of the business model compare with that of traditional IE variables? Event history methodology cannot answer 
that question, as it does not easily allow us to compare the degree of fit between a model with only traditional IE variables and one with only global niche business model variables. We can, however, run three logit models, one with only IE explanatory variables, another with only niche business model variables, and a third one with both. In these models, the dependent variable is the probability of being a BG (to reach $25 \%$ foreign sales within three years), with a positive coefficient contributing to that probability. Because logit models are sensitive to small samples, we replace the global niche business model variables with Niche BM Index, the formative scale described earlier.

Table 6 reports the results of the three logistic models we ran to compare the relative explanatory power of IE and business model variables. Model (1) includes the two previously significant IE variables, Years Worked Abroad and Years in Import-Export, as well as Regional Export Intensity, the control variable found previously significant. In Model (2) we enter, along with Regional Export Intensity, our Niche BM Index variable which captures the business model characteristics that lead to fast internationalization. Model (3) includes both sets of variables. The signs and significance levels of the variables remain unchanged. In Model (1) Years Worked Abroad and Years in Import-Export remain significant. The model has a pseudo $R^{2}$ of $7.81 \%$ and classifies correctly $80.18 \%$ of all observations with a $\mathrm{LR} \mathrm{Chi}^{2}$ of 15.88 $(p<0.000)$. In Model (2) we only include Niche BM Index. As expected, its coefficient is positive and strongly significant with a $p$ value of 0.00003 . The model's pseudo $R^{2}$ jumps to $13.36 \%$, the percentage of observations correctly classified to $82.43 \%$, and the LR $\mathrm{Chi}^{2}$ to $27.15(p<0.000)$. These results show that global niche business model variables are better predictors of the speed at which firms develop their foreign sales than traditional IE variables, explaining a higher level of variance with greater accuracy. Model (3) combines both sets of variables. The coefficients of the variables are similar, but the fit of the model increases, with the pseudo- $R^{2}$ reaching $17.77 \%$, the percentage of correct predictions now at $85.14 \%$ and the LR $\mathrm{Chi}^{2}$ at $33.86(p<0.000)$. Thus, entering Niche BM Index along with the IE variables greatly improves the model likelihood and its accuracy over a null model. The values of the likelihood ratio test of the nested models (Models 1 and 2) versus the full model (Model 3) show that the improvement in fit is larger when comparing the full model to Model 1
(20.23) than to Model 2 (8.95), indicating that Model 2 has a statistically significant higher fit compared to Model 1. This suggests that a full explanation of how fast firms can grow their foreign sales should take into account both a firm's business model and the work experience of its founders/managers. Overall, our results strongly support our first hypothesis (H1) that a firm's business model has a strong impact on the time it takes to reach BG status. More precisely, we find that firms that are structurally quicker to internationalize are those that follow a niche business model.

\section{Robustness Tests and Additional Analyses}

We ran the event history model of Table 5 with a six-year observation window to see if our results hold up with a less stringent BG definition. The results are reported in Table 7, Models 1 and 2. The coefficients of the IE variables remain unchanged. There are slight changes for the BM variables: Many Clients becomes statistically significant (with the expected negative sign) while B2C loses significance. The Niche BM Index variable remains strongly significant, confirming our main hypothesis. We also ran the logit models of Table 6 using the sixyears definition of BG and ran our main event history and logit models with a version of the Niche $B M$ Index that excludes B2C and Many Clients. None of those changes affected our results. ${ }^{22}$

Overall, our findings show that firms with a global niche business model and those with founders who have worked abroad are faster internationalizers. What is the nature of the relationship between these two constructs? A possible one is mediation. The impact of founders with international experience may work through their selection of a niche business model. If this was true, the business model variables and the Niche BM Index would lose significance in the presence of the entrepreneurial experience variables. As shown by Models 1 and 2 in Table 5 (for the three-year window) and in Table 7 (for the six-year window), this is not the case.

It can also be that a founder's international work experience positively moderates the relationship between a global niche business model and fast foreign sales growth. In other words, founders with international experience may be more likely to capitalize on a global niche business model than those with less international experience. We test this hypothesis in Models 3 and 4 of Table 7 by interacting our Niche BM Index variable with the 


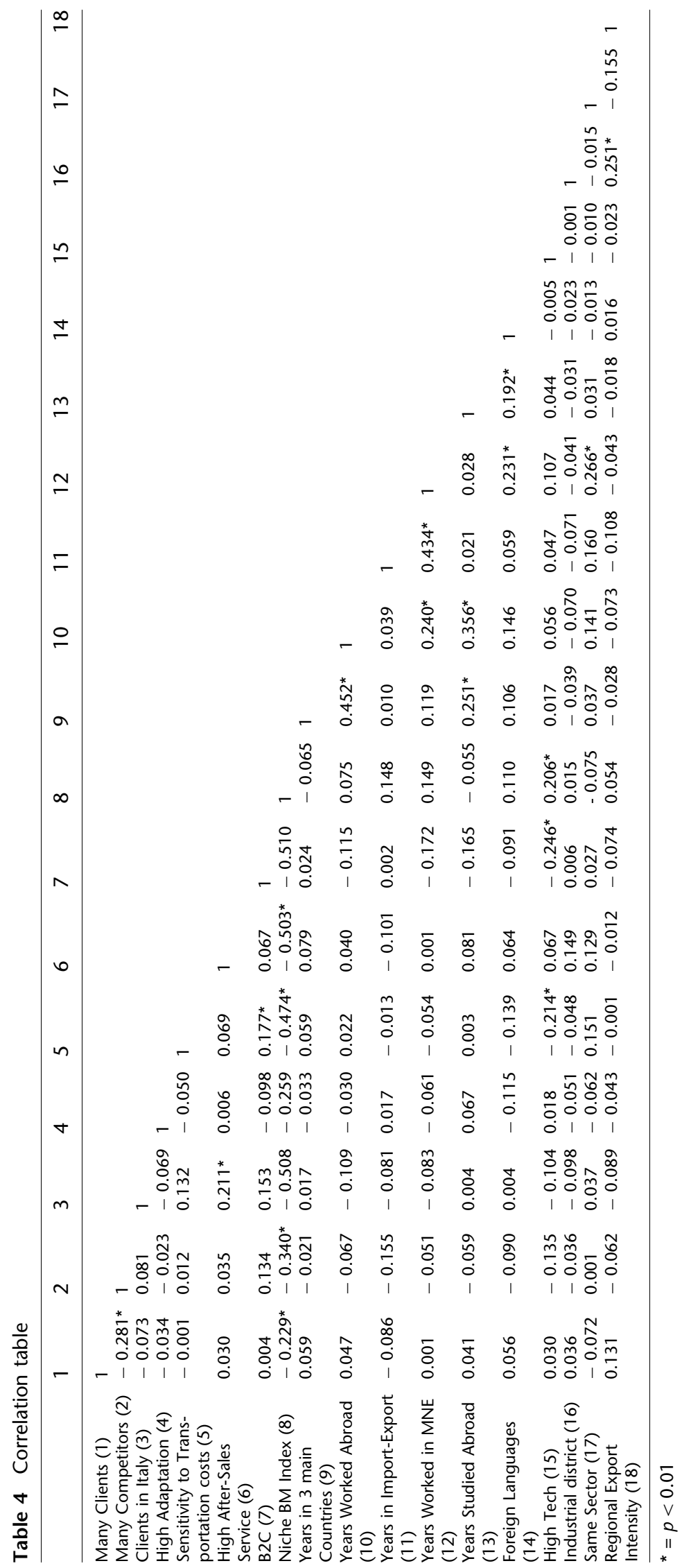


Table 5 Determinants of time to Born Global status (three-year window)

\begin{tabular}{|c|c|c|c|c|}
\hline Variables & 1 & $p$ values & 2 & $p$ values \\
\hline Many Clients & $\begin{array}{l}0.413 \\
(0.378)\end{array}$ & 0.273 & & \\
\hline Many Competitors & $\begin{array}{l}-0.635 \\
(0.383)\end{array}$ & 0.097 & & \\
\hline Clients in Italy & $\begin{array}{l}-0.013 \\
(0.005)\end{array}$ & 0.014 & & \\
\hline High Adaptation & $\begin{array}{l}-0.009 \\
(0.004)\end{array}$ & 0.033 & & \\
\hline Sensitivity to Transp. Costs & $\begin{array}{l}-0.014 \\
(0.006)\end{array}$ & 0.016 & & \\
\hline High After-Sales Service & $\begin{array}{l}-0.013 \\
(0.005)\end{array}$ & 0.008 & & \\
\hline $\mathrm{B} 2 \mathrm{C}$ & $\begin{array}{l}-0.648 \\
(0.378)\end{array}$ & 0.086 & & \\
\hline Niche BM Index & & & $\begin{array}{l}0.327 \\
(0.074)\end{array}$ & 0.000 \\
\hline Years Worked Abroad & $\begin{array}{l}0.114 \\
(0.041)\end{array}$ & 0.005 & $\begin{array}{l}0.108 \\
(0.042)\end{array}$ & 0.010 \\
\hline Years in 3 Main Countries & $\begin{array}{l}0.001 \\
(0.048)\end{array}$ & 0.981 & $\begin{array}{l}0.004 \\
(0.047)\end{array}$ & 0.923 \\
\hline Years in Import-Export & $\begin{array}{l}0.062 \\
(0.034)\end{array}$ & 0.078 & $\begin{array}{l}0.043 \\
(0.034)\end{array}$ & 0.205 \\
\hline Years Worked in MNE & $\begin{array}{l}-0.048 \\
(0.032)\end{array}$ & 0.139 & $\begin{array}{l}-0.037 \\
(0.032)\end{array}$ & 0.794 \\
\hline Years Studied Abroad & $\begin{array}{l}0.012 \\
(0.085)\end{array}$ & 0.887 & $\begin{array}{l}-0.024 \\
(0.091)\end{array}$ & 0.794 \\
\hline Foreign Languages & $\begin{array}{l}0.027 \\
(0.206)\end{array}$ & 0.895 & $\begin{array}{l}0.021 \\
(0.189)\end{array}$ & 0.911 \\
\hline High-Tech & $\begin{array}{l}-0.012 \\
(0.008)\end{array}$ & 0.130 & $\begin{array}{l}-0.009 \\
(0.006)\end{array}$ & 0.176 \\
\hline Industrial District & $\begin{array}{l}0.357 \\
(0.512)\end{array}$ & 0.486 & $\begin{array}{l}0.281 \\
(0.469)\end{array}$ & 0.549 \\
\hline Same Sector & $\begin{array}{l}0.011 \\
(0.016)\end{array}$ & 0.488 & $\begin{array}{l}0.010 \\
(0.016)\end{array}$ & 0.528 \\
\hline Regional Export Intensity & $\begin{array}{l}5.171 \\
(2.611)\end{array}$ & 0.048 & $\begin{array}{l}6.146 \\
(2.589)\end{array}$ & 0.018 \\
\hline (dof) & (17) & & (11) & \\
\hline LR chi2 & 50.30 & 0.000 & 39.89 & 0.000 \\
\hline Observations & 222 & & 222 & \\
\hline
\end{tabular}

Standard errors in parentheses.

number of years the most experienced member of the team has worked abroad, Years Worked Abroad. The coefficient of Niche BM Index*Years Worked Abroad is not significant ( $p$ value $=0.408$ in Model 3 and 0.463 in Model 4), providing no support for the idea that a global niche business model will result in faster internationalization if the founders carrying it out are internationally experienced. To investigate this further, we test the possibility of a partial mediation effect between international experience and business model choice. To do so, we regress the experience variables (Years Worked
Abroad, Years in 3 Main Countries, Years in ImportExport, Years Worked in MNE, Years Studied abroad, Foreign Languages) against the Niche BM Index (dependent variable) using both Tobit and OLS regression. The experience variables are statistically insignificant in all runs, failing to support the idea that international experience drives the choice of business model. $^{23}$

Overall, our additional tests strongly confirm our main result which is that a firm's business model explains most of the variance in its internationalization speed. 


\section{DISCUSSION AND CONCLUSION}

The Uppsala model and export development process theories posit that because selling abroad requires understanding previously unknown environments and adapting to them, firms will expand their foreign sales very slowly. The existence of born globals (BGs), firms that sell abroad a substantial share of their output immediately or within a few years of founding, thus presents a theoretical challenge.

To explain this anomaly, most BG scholars have looked for special circumstances under which Uppsala and export development process theories do not apply. They have argued that BGs are fast internationalizers because they use networks and possess unique attributes, such as superior technology and founders with a high international orientation who "seem to discount the risk of going international" (Cavusgil \& Knight, 2015: 10).

We take a different approach. Following Hennart (2014), we argue that an important reason for the rapid international expansion of some firms has to do with their business model. That is, some firms have business models that facilitate rapid foreign sales growth, while others do not: firms characterized by a niche business model are able to export from their home base products and services that do not require host country-specific marketing mix adaptations and do not need foreign-based aftersales service, and this allows them to expand foreign sales quickly and to become BGs. Using event history methodology, we test this hypothesis by looking at the time it took Italian SMEs to reach BG status, i.e., to sell a quarter of their output to foreign customers. We compare the impact of a firm's business model on its internationalization speed with that of traditional IE variables, such as whether the firm makes extensive use of networks, whether its products are high-tech, and whether its founders are internationally experienced. Most of the business model variables turn out to be statistically significant, while among the traditional IE variables, only the founder's prior foreign work experience receives consistent statistical support. We find that a model that includes only business model variables has greater explanatory power than one that only features traditional IE variables. Adding business model variables to a model with IE variables substantially improves fit.

Before discussing the implications of these findings, one should keep in mind their limitations.

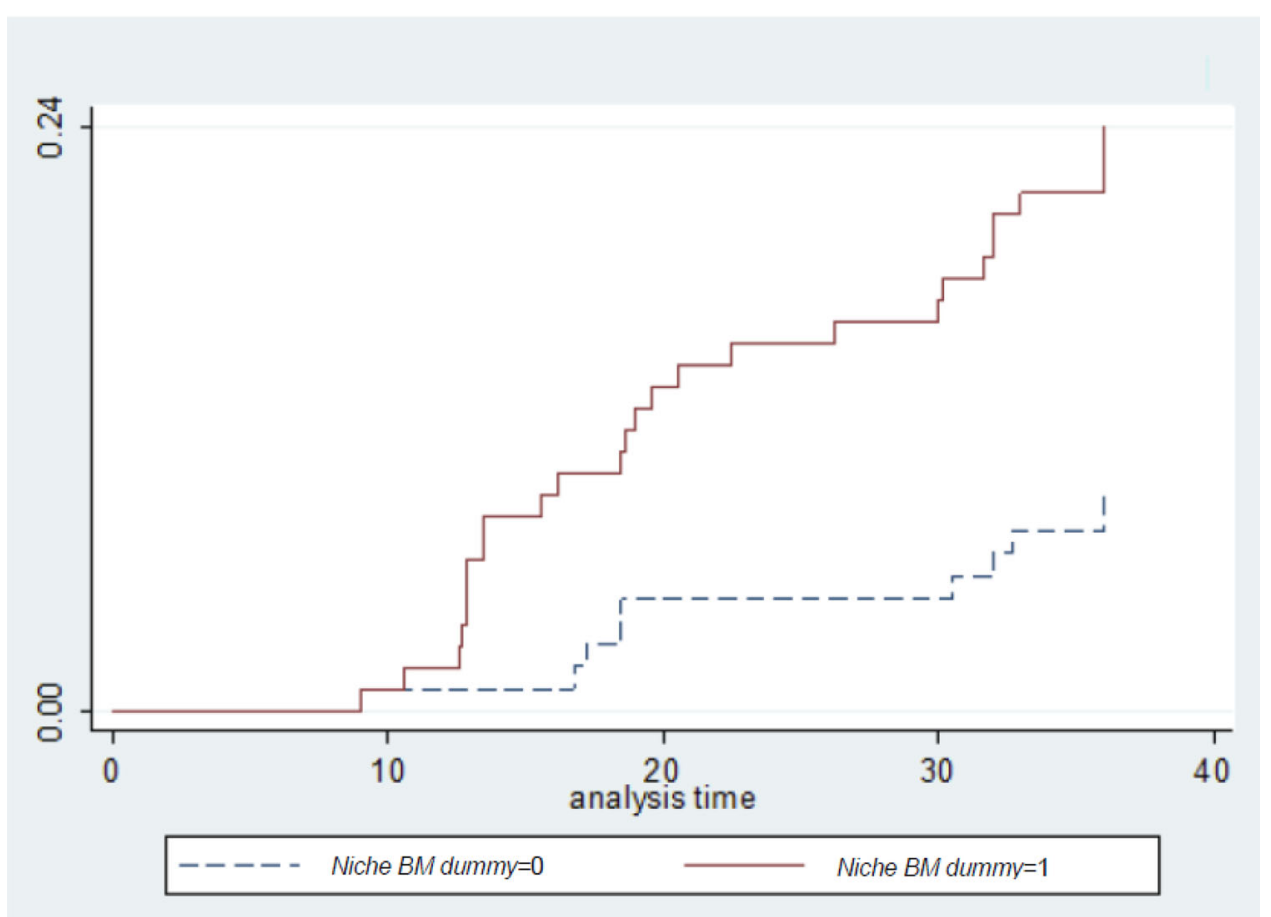

Figure 1 Inverse Kaplan-Meier survival functions for firms with a Niche BM Index above and below the mean. Cumulative percentage of firms reaching $25 \%$ foreign sales from time of first sale for firms with a Niche BM Index above the mean (Niche BM dummy = 1 ; solid line) and below the mean (Niche BM dummy =0; dotted line). 
Two of them are imposed on us by our desire to compare the explanatory power of business modelbased variables to those put forth by the extant IE literature. First, we focus on the variables that affect the speed with which a firm sells to foreign final customers, the facet of firm internationalization on which the Uppsala model, export development process models, and the BG literature have focused. Hence, we look at a firm's downstream activities, not at its upstream internationalization, such as the offshoring of components, assembly, or $R \& D$. Second, and again in keeping with the bulk of the BG literature, we measure the degree of internationalization by the ratio of foreign to total sales (FSTS). This has clear limitations, since firms with the same FSTS may differ in their internationalization breadth, with some selling regionally and others globally (Rugman, Verbeke \& Nguyen, 2011; Sleuwaegen \& Onkelinx, 2014). This paper also suffers from other limitations. We did not test all the business model dimensions that might affect a firm's speed of international expansion. For example, we did not ask respondents how much promotion and advertising was required to sell their products. Another possible limitation is that we are measuring the size of an entrepreneur's foreign network at inception by international experience. Although it is generally agreed that entrepreneurs add foreigners to their social network when they spend time abroad, a variable already included in our model, a direct measure of an entrepreneur's foreign social network would have been preferable. We also measure a firm's technological intensity by asking the entrepreneur to rate it, and although many authors have argued that this measure is the most appropriate one for SMEs, it still suffers from the problem of being subjective. BGs may also aggressively expand abroad because they want to capture first mover advantages (Herbig, Howard \& Kramer, 1995). We did not specifically test for that. We focus on a single country, Italy. Since the decision to sell abroad depends on the relative advantage of foreign over domestic sales, we would expect the ratio of foreign to total sales to depend not only on the attractiveness of selling abroad but also on that of selling at home. By focusing on a single country, Italy, we keep constant the domestic factors that might influence this choice. On the other hand, our results may not be fully generalizable to other settings. Note also that we ignore long-term financial performance - we do not investigate whether the firms in our sample that were quick to sell abroad were more or less financially successful in the long term than those that followed the slow Uppsala model approach.

In spite of these limitations, we believe that this paper makes significant contributions to the BG literature and to IB theory. First, it is the first, as far as we know, to empirically assess how much a firm's internationalization speed depends on its business model, and how much on traditional IE variables, such as prior international experience of founders, use of networks, and technological intensity. While Dow (2017) made a serious effort to test the significance of the first set of variables, he did

Table 6 Determinants of the probability a firm will be a born global ( $25 \%$ foreign sales in three years)

\begin{tabular}{|c|c|c|c|c|c|c|}
\hline Variables & $\begin{array}{l}\text { (1) } \\
\text { IE only }\end{array}$ & $p$ values & $\begin{array}{l}\text { (2) } \\
\text { BM only }\end{array}$ & $p$ values & $\begin{array}{l}\text { (3) } \\
\mathrm{IE}+\mathrm{BM}\end{array}$ & $p$ values \\
\hline Niche BM Index & & & $\begin{array}{l}0.333 \\
(0.076)\end{array}$ & 0.000 & $\begin{array}{l}0.328 \\
(0.079)\end{array}$ & 0.000 \\
\hline Years Worked Abroad & $\begin{array}{l}0.108 \\
(0.042)\end{array}$ & 0.001 & & & $\begin{array}{l}0.112 \\
(0.044)\end{array}$ & 0.011 \\
\hline Years in Import-Export & $\begin{array}{l}0.083 \\
(0.041)\end{array}$ & 0.043 & & & $\begin{array}{l}0.058 \\
(0.045)\end{array}$ & 0.200 \\
\hline Regional Export Intensity & $\begin{array}{l}6.412 \\
(2.621)\end{array}$ & 0.014 & $\begin{array}{l}4.994 \\
(2.513)\end{array}$ & 0.047 & $\begin{array}{l}7.470 \\
(2.975)\end{array}$ & 0.012 \\
\hline Constant & $\begin{array}{l}-3.318 \\
(0.705)\end{array}$ & 0.000 & $\begin{array}{l}-3.017 \\
(0.665)\end{array}$ & 0.000 & $\begin{array}{l}-3.837 \\
(0.830)\end{array}$ & 0.000 \\
\hline Pseudo- $\mathrm{R}^{2}$ & $7.81 \%$ & & $13.36 \%$ & & $17.77 \%$ & \\
\hline LR Chi ${ }^{2}$ (dof) & $15.88(3)$ & 0.001 & $27.15(2)$ & 0.000 & $33.86(4)$ & 0.000 \\
\hline Correctly classified (\%) & $80.18 \%$ & & $82.43 \%$ & & $85.14 \%$ & \\
\hline Lr test nested vs. full model & (1) 20.23 & 0.000 & (2) 8.95 & 0.000 & Full & \\
\hline Observations & 222 & & 222 & & 222 & \\
\hline
\end{tabular}

Standard errors in parentheses. 
Table 7 Determinants of time to Born Global status (6-year window) and models with interaction terms (3- and 6-year windows)

\begin{tabular}{|c|c|c|c|c|c|c|c|c|}
\hline \multirow[t]{3}{*}{ Variables } & \multicolumn{4}{|c|}{ 6-year window } & \multicolumn{4}{|c|}{ Models with interaction } \\
\hline & \multirow[t]{2}{*}{ Model 1} & \multirow[t]{2}{*}{$p$ values } & \multirow[t]{2}{*}{ Model 2} & \multirow[t]{2}{*}{$p$ values } & \multicolumn{2}{|c|}{ 3-year window } & \multicolumn{2}{|c|}{ 6-year window } \\
\hline & & & & & Model 3 & $p$ values & Model 4 & $p$ values \\
\hline Many Clients & $\begin{array}{l}0.741 \\
(0.310)\end{array}$ & 0.017 & & & & & & \\
\hline Many Competitors & $\begin{array}{l}-0.591 \\
(0.327)\end{array}$ & 0.071 & & & & & & \\
\hline Clients in Italy & $\begin{array}{l}-0.017 \\
(0.005)\end{array}$ & 0.000 & & & & & & \\
\hline High Adaptation & $\begin{array}{l}-0.010 \\
(0.004)\end{array}$ & 0.007 & & & & & & \\
\hline Sensitivity to Transp. Costs & $\begin{array}{l}-0.010 \\
(0.005)\end{array}$ & 0.044 & & & & & & \\
\hline High After-Sales Service & $\begin{array}{l}-0.009 \\
(0.004)\end{array}$ & 0.019 & & & & & & \\
\hline $\mathrm{B} 2 \mathrm{C}$ & $\begin{array}{l}-0.497 \\
(0.313)\end{array}$ & 0.112 & & & & & & \\
\hline Niche BM Index & & & $\begin{array}{l}0.271 \\
(0.061)\end{array}$ & 0.000 & $\begin{array}{l}0.345 \\
(0.077)\end{array}$ & 0.000 & $\begin{array}{l}0.285 \\
(0.064)\end{array}$ & 0.000 \\
\hline Niche BM Index*Years Worked Abroad & & & & & $\begin{array}{l}-0.155 \\
(0.019)\end{array}$ & 0.408 & $\begin{array}{l}-0.011 \\
(0.0156)\end{array}$ & 0.463 \\
\hline Years Worked Abroad & $\begin{array}{l}0.119 \\
(0.035)\end{array}$ & 0.001 & $\begin{array}{l}0.105 \\
(0.033)\end{array}$ & 0.002 & $\begin{array}{l}0.139 \\
(0.054)\end{array}$ & 0.010 & $\begin{array}{l}0.127 \\
(0.044)\end{array}$ & 0.004 \\
\hline Years in 3 Main Countries & $\begin{array}{l}-0.025 \\
(0.045)\end{array}$ & 0.573 & $\begin{array}{l}-0.016 \\
(0.041)\end{array}$ & 0.693 & $\begin{array}{l}-0.002 \\
(0.046)\end{array}$ & 0.968 & $\begin{array}{l}-0.013 \\
(0.039)\end{array}$ & 0.736 \\
\hline Years in Import-Export & $\begin{array}{l}0.059 \\
(0.031)\end{array}$ & 0.053 & $\begin{array}{l}0.037 \\
(0.030)\end{array}$ & 0.215 & $\begin{array}{l}0.051 \\
(0.035)\end{array}$ & 0.149 & $\begin{array}{l}0.042 \\
(0.031)\end{array}$ & 0.173 \\
\hline Years Worked in MNE & $\begin{array}{l}-0.045 \\
(0.026)\end{array}$ & 0.080 & $\begin{array}{l}-0.030 \\
(0.024)\end{array}$ & 0.222 & $\begin{array}{l}-0.046 \\
(0.035)\end{array}$ & 0.194 & $\begin{array}{l}-0.036 \\
(0.026)\end{array}$ & 0.177 \\
\hline Years Studied Abroad & $\begin{array}{l}-0.025 \\
(0.079)\end{array}$ & 0.796 & $\begin{array}{l}-0.018 \\
(0.088)\end{array}$ & 0.835 & $\begin{array}{l}-0.042 \\
(0.119)\end{array}$ & 0.727 & $\begin{array}{l}-0.068 \\
(0.112)\end{array}$ & 0.540 \\
\hline Foreign Languages & $\begin{array}{l}0.193 \\
(0.165)\end{array}$ & 0.242 & $\begin{array}{l}0.201 \\
(0.150)\end{array}$ & .180 & $\begin{array}{l}0.024 \\
(0.184)\end{array}$ & 0.894 & $\begin{array}{l}0.194 \\
(0.148)\end{array}$ & 0.191 \\
\hline High Tech & $\begin{array}{l}-0.006 \\
(0.007)\end{array}$ & 0.386 & $\begin{array}{l}-0.002 \\
(0.006)\end{array}$ & 0.668 & $\begin{array}{l}-0.008 \\
(0.007)\end{array}$ & 0.233 & $\begin{array}{l}-0.002 \\
(0.006)\end{array}$ & 0.772 \\
\hline Industrial District & $\begin{array}{l}-0.188 \\
(0.494)\end{array}$ & 0.704 & $\begin{array}{l}-0.170 \\
(0.450)\end{array}$ & 0.706 & $\begin{array}{l}0.326 \\
(0.473)\end{array}$ & 0.491 & $\begin{array}{l}-0.140 \\
(0.452)\end{array}$ & 0.756 \\
\hline Same Sector & $\begin{array}{l}0.022 \\
(0.012)\end{array}$ & 0.064 & $\begin{array}{l}0.020 \\
(0.012)\end{array}$ & 0.090 & $\begin{array}{l}0.011 \\
(0.016)\end{array}$ & 0.518 & $\begin{array}{l}0.020 \\
(0.011)\end{array}$ & 0.082 \\
\hline $\begin{array}{l}\text { Regional Export Intensity } \\
\text { (dof) }\end{array}$ & $\begin{array}{l}5.221 \\
(2.123) \\
(17)\end{array}$ & 0.014 & $\begin{array}{l}6.471 \\
(2.104) \\
(11)\end{array}$ & 0.002 & $\begin{array}{l}5.560 \\
(2.624) \\
(12)\end{array}$ & 0.034 & $\begin{array}{l}6.052 \\
(2.143) \\
(12)\end{array}$ & 0.005 \\
\hline LR chi2 & 71.99 & 0.000 & 47.33 & 0.000 & 40.57 & 0.000 & 47.86 & 0.000 \\
\hline Observations & 222 & & 222 & & 222 & & 222 & \\
\hline
\end{tabular}

Standard errors in parentheses.

not have the data to simultaneously enter IE variables, and so was unable to determine the relative strength of his business model variables compared to traditional IE ones. Second, we articulate a clear logic of why using a niche business model will speed up foreign sales and use a more comprehensive set of variables to define it than in the small number of previous studies entering this variable. With the exception of Zucchella et al. (2007), our measures of founder experience are also more comprehensive than those used in past studies. Third, we are, as far as we know, the first to use event history analysis to study the determinants of fast internationalization, a significant methodological improvement over the logistic models used in previous BG studies. Our dependent 
variable is the time it took for a firm to reach BG status $(25 \%$ foreign sales in either three or six years). Previous research has classified as BGs firms that reach a certain percentage of foreign sales, usually $25 \%$, in a given time span, usually three years, and has used logistic regression to predict whether a given firm falls in that category. Besides being somewhat arbitrary, the $25 \%$ in three-year criterion is also context specific, since reaching this target is not particularly hard for a firm based in a small European Union country. Furthermore, this methodology is also very coarse, since a firm with zero and one with $24.9 \%$ foreign sales are both categorized as non-BG. By using event history, on the other hand, we are able to transform this dichotomous variable into a continuous one, the length of time it takes a firm to reach a certain percentage of foreign sales.

Second, our results, which are robust to alternative measures of our dependent variable, open new perspectives for BG research. While the IE literature has argued that the international orientation of founders goes a long way in explaining the internationalization of their firm (e.g., Knight \& Liesch, 2016) and have made considerable effort in measuring it, we show that the way this variable has been measured is deeply flawed - it is logical to expect the ex post responses of successful international entrepreneurs to display a strong orientation towards international entrepreneurship. Rather, we suggest looking at the likely antecedent of global orientation, prior international experience. As shown by our results, that variable has a more ambiguous impact on a firm's foreign sales growth than generally thought. Along with Dib et al. (2010), Vissak et al. (2012), and Zucchella et al. (2007), we find that a founder's study abroad has no impact on the speed of foreign sales expansion. The same is true for prior foreign language fluency contrary to Zucchella et al. (2007). Consistent with Vissak et al. (2012) but not with Wickramasekera and Bamberry (2003) and Zucchella et al. (2007), we also find no statistical link between having worked for an MNE and fast foreign expansion. Lastly, we find no statistical relationship between having previously worked and/or studied in one of the three main markets where the firm was active at the time of the survey and the speed of its foreign sales. This finding goes against the predictions of the Uppsala model since founders who have earlier spent time in a country where their firms sell today should have been able to short-circuit the accumulation of experiential knowledge, and thus to turbo-charge foreign sales.

There are two possible explanations for the lack of support for a relationship between countryspecific experience and internationalization speed. One is that, contrary to what is posited by the Uppsala model, that kind of experience matters less than general experience with the international environment, as the latter alerts founders to the possibility of profitably selling abroad. The second explanation is that, while it makes sense to assume that prior host-country experience should speed up the international expansion of mass market firms, it is unclear how it should benefit firms that follow a niche business model, i.e., that sell products that do not require foreign customer prospection, country-based adaptation, and the establishment of foreign production facilities, all tasks that benefit from host-country experience. If you have distinctive products, customers are likely to beat a path to your door. Because customers of niche products have universal needs, niche products do not have to be adapted in each target country, making knowing how to do this unnecessary. Likewise, experience in managing operations in a particular foreign country is not needed if products can be exported. It stands to reason therefore that some founders may quickly develop foreign sales in spite of a total lack of foreign host-country experience. They may be "accidental internationalists" as proposed by Hennart (2014). In fact, 28 of the 38 BGs in our sample had founders with zero prior foreign work experience.

Contrary to IE views on BGs, and along with Dow (2017), we find that a firm's technological intensity has no impact on its internationalization speed. We have argued that the crucial characteristic of a product and service that affects the speed at which it can be sold abroad is its uniqueness. Hightechnology products are sometimes distinctive or unique because they incorporate proprietary technology, but so are high-design products, and those for which quality arises from a unique provenance, like Gevrey Chambertin wine and Cancale oysters. This suggests that IE scholars may have overemphasized the role that technology plays in a firm's internationalization speed.

Dow (2017) notes that the IE literature on BGs has tended to assume that they are a different and unique type of firm and so has analyzed them in isolation. Indeed, studies that compare BGs to nonBGs are a very small subset of the BG literature. Our results show that one important difference between 
BGs and non-BGs is in the business model used. This has a number of implications for IB theory. First, if a main difference between BGs and nonBGs is that they use a different business model, then there are no reasons why BGs cannot be explained by mainstream theories. Our findings support the claim of Verbeke et al. (2014) and Verbeke and Ciravegna (2018) that internalization theory can explain both. The Uppsala model describes cases where the firm's FSAs must be extensively combined with complementary resources in the target market. The firm must therefore negotiate with local suppliers of complementary resources. This takes time, and requires experiential knowledge of the specific target market, which also takes time to accumulate. Hence, the pace of a firm's foreign expansion will be slow. Whenever the firm's FSAs can be exploited abroad without extensive combination with local resources, the firm can expand abroad more rapidly, and, in some cases, instantaneously. This occurs when a firm can exploit its FSAs without having to set up production or after-sales facilities abroad because it sells to a global customer base an exportable niche product which requires no or little customer prospecting and advertising, no targetcountry adaptation, and no local service. A firm that sells distinctive niche products can also shift to the buyer the tasks of arranging transport and custom clearance, thus speeding up foreign sales. All in all, sellers of niche products may be able to circumvent all of the export barriers listed by Leonidou (2004): lack of knowledge of foreign customers, need to make country-specific marketing adjustments, high transportation costs, high trade barriers, and currency and political risk.

The IE literature has also stressed that SMEs have difficulty internationalizing because they suffer from a liability of foreignness and of smallness. Zaheer (1995) has argued that firms suffer a liability of foreignness because they do not know how to do business in a foreign country, because they are subject to discrimination by host-country governments, because they are constrained by the policies of their own government, and because they experience difficulties in managing their foreign subsidiaries. It is easy to show that SMEs with global niche business models can alleviate such liabilities. They can serve their customers through exports, and hence avoid the problems inherent in managing foreign subsidiaries at a distance and in unknown environments. The lack of physical presence in foreign countries also reduces exposure to target country discrimination because it drastically curtails foreign footprint and visibility. Some authors have also argued that small firms are at a disadvantage - they incur a liability of smallness because they cannot take advantage of economies of scale and suffer from a lack of legitimacy and market power (Mellahi \& Wilkinson, 2004). Firms with a global niche business model are less likely to suffer from this liability because they can expand abroad with exports, which requires less investment, and because they tend to dominate their niche, giving them market power and legitimacy (Merrilees \& Tiessen, 1999).

We also advance IB theory by using a business model lens to analyze the micro-foundations of a firm's FSAs. Dunning (1988) initially defined FSAs as intangibles, such as advanced technology and internationally recognized brand names, and argued that they could be exploited worldwide. Yet casual observation shows that the initial success of some of the most profitable of today's MNEs has not been based on their advanced products and well-known brand names. The clothes sold by Zara do not differ substantially from those sold by H\&M, Ikea's furniture is similar to that sold by many other retailers, and Ryanair's Boeing 737-800 planes are also used by other airlines. The brand names of these firms were not known when they started. However, each of them developed a unique business model which it leveraged worldwide. The reason for their success rests not on what they sell, but on how they sell it. So, besides superior technology and reputable brand names, unique business models are also FSAs (Bohnsack et al, 2020). In fact, the bundling (Hennart, 2009; Teece, 1986) and the business model approaches both stress that superior technology or great reputation are insufficient to assure profitability and worldwide expansion because the firm must also manage the supply of all complementary resources. Without the efficient orchestration of these resources, the firm will not be able to exploit its intangibles. So, in the end, every successful business model is an FSA.

A business model approach thus prompts us to go beyond intangibles and to take a more holistic - but also more detailed - look at what makes it possible for firms to successfully sell abroad (Bohnsack et al., 2020). In our case, we distinguish between two generic business models, a mass market one and a niche one, and ascertain how they affect the speed with which firms sell abroad. An important insight of the business model approach is the need for 
coherence between its constituting elements. As Magretta (2002: 6) puts it, the business model approach shows "how the pieces of a business fit together". This is clear in our case. Satisfying very particular needs and tastes implies few competitors and few customers. These customers are likely to be geographically dispersed, few in number in any given country, making it possible and efficient to serve them through exports, both because they are willing to pay shipping costs and because there are too few of them in any given country to justify locating a production plant there. Customers of niche products are more likely to have homogeneous tastes, and to be more knowledgeable about what they want and more proactive in finding it, thus reducing marketing costs. All of these features, which are internally consistent, make for quicker international expansion.

At the same time, a business model view prompts us to go much deeper and to look at how subtle differences in business models affect that speed. Consider Atlassian and Jive. These two firms sell computer programs that perform the same functions, but Atlassian's software is sold as a standalone product downloadable from its website at a price that is likely to be within the discretionary budget of individual programmers, while Jive's is bundled with other software and sold by salespeople to IT directors. As Jive's business model requires a salesforce based in a target country and all the investment and management that this entails, it is not surprising that its international expansion has been much slower than that of Atlassian (Hennart, 2014). To explain how quickly a firm will sell abroad, one must therefore consider all the elements of its business model, for example the type of customers it targets, how it serves them, and how it captures a part of the value delivered. We believe that this holistic - but also detailed - approach makes the business model particularly useful for the study of internationalization speed.

Our results also raise new questions. We find that both a firm's business model and the work experience of its entrepreneurial team have a positive impact on the speed at which it develops its foreign sales. Dow (2017) ventures that the FSA/business model and the IE approach are more complementary than contradictory. He proposes that business model variables set up the conditions under which firms can quickly rack up foreign sales, but that it is founders with international experience who realize this potential. He was, however, unable to put this hypothesis to the test because he did not have data on the international experience of the entrepreneurs in his sample. In Table 7 , the interaction between our niche business model index (Niche BM Index) and prior international work experience of a firm's entrepreneurial team (Years Worked Abroad) is not statistically significant. In contrast to Autio (2017), we find that a founder's international work experience does not turbo-charge a niche business model towards faster internationalization. Furthermore, we find that internationally experienced founders are not more likely to opt for a global niche business model than inexperienced ones. In other words, our results show that the international work experience of the most international member of the entrepreneurial team and the firm's choice of a global niche business model exert a separate positive influence on internationalization speed. These provocative findings should be further investigated. Note, however, that we are looking at internationalization speed, not at internationalization performance. Perhaps a firm with a global niche business model but internationally inexperienced founders will eventually fail, just like one with internationally experienced founders who charge ahead in going abroad without the right business model.

This study is only a first pass at investigating how a firm's business model affects its sales growth. We distinguish between a mass-market and a niche business model, but more research is needed on this. It might make sense, for example, to identify all business model archetypes that lead to fast internationalization.

So what is distinctive about born globals? We find that it is their business model and the international work experience of their founders, with the former explaining a larger share of the variance than the latter.

\section{ACKNOWLEDGEMENTS}

We received useful comments from Alain Verbeke, three anonymous referees, an anonymous reader, and from participants at the 2019 Vaasa International Business conference and at seminars at the University of Tübingen, WU Vienna, KU Leuven, Tilburg University, the University of Pavia, the Free University of Bolzano, the University of Lausanne, Politecnico di Milano, Trinity College Business School, the University of Reading, King's College London, University of Venice Ca'Foscari, Bocconi, Copenhagen Business School, the University of Manchester, Università della 
Svizzera Italiana, and the Smurfit School of Business at University College Dublin. We thank Tilburg University School of Economics and Management for providing Open Access.

\section{NOTES}

${ }^{1} \mathrm{We}$ are well aware of the criticism that the term BG can be seen as misleading, as BGs often do not sell in many dissimilar foreign countries but instead within a single foreign region or to a limited number of foreign countries (Coviello, 2015; Kuivalainen et al., 2007; Lopez, Kundu \& Ciravegna, 2009). It has also been said that a threshold of $25 \%$ foreign sales in three years is not overly ambitious (Verbeke et al., 2014). With this caveat in mind, we use the term BG because, like the BG literature and in contrast to that on international new ventures (INVs) (Oviatt \& McDougall, 1994), we focus on firm downstream internationalization and not on that of upstream activities like R\&D and manufacturing (Coviello, 2015). Unlike the BG literature, however, we do not adhere to a rigid definition of what it takes to be a BG, because our dependent variable is the speed at which a firm develops foreign sales. That speed can be evaluated against any internationalization milepost (25\% or more) and any time frame (three years or less).

${ }^{2}$ See below for further discussion of the business model concept.

${ }^{3}$ We measure foreign sales as exports plus local production for local customers.

${ }^{4}$ See below for a description of event history methodology.

${ }^{5}$ Like in medical studies, ours has a set observation period, which we chose to coincide with those generally used in the BG literature. Hence, we study the factors that determine how long it takes for firms to reach $25 \%$ foreign sales within a three-year and a six-year time frame, with those firms that have not reached that milepost right-censored.

${ }^{6}$ Psychic distance is defined as "the sum of the factors preventing flow of information from and to the market" (Johanson \& Vahlne, 1977:24).

${ }^{7}$ Oviatt and McDougall had in 1994 called these firms international new ventures (INVs). While the INV literature has been interested in both upstream and downstream internationalization, the BG literature has focused on downstream internationalization. Because we focus on the latter, we make reference to BG studies.

${ }^{8} \mathrm{We}$ thank an anonymous referee for this point.
${ }^{9}$ Rialp, Rialp, and Knight (2005: 159) call the existence of such low-tech BGs a "discrepancy", thus acknowledging they do not fit with the dominant view that high technological intensity is a prerequisite for being a BG. They argue that "a possible explanation for this controversial empirical fact" is that "born globals originating in countries with large home markets are mostly found in high technology sectors, while born globals in smaller countries are more often found in other sectors".

${ }^{10}$ Acer found this out when it introduced its Aspire personal computer in the US. The PC was targeted to novice customers, and Acer was unable to handle the volume of their questions (Bartlett \& George, 1998).

${ }^{11}$ The fact that BGs tend to specialize in niche products has been noticed by some IE authors (e.g., Cannone \& Ughetto, 2014; Dib et al., 2010; Moen, 2002; Nummela et al., 2004a; Zucchella et al., 2007). Dow (2017) notes, however, that the IE literature has paid only limited attention to this and has instead continued to focus on entrepreneurs and their orientations.

${ }^{12} \mathrm{~A}$ razor and blade business model is one where a product is sold at a loss or at cost, with the sale of a paired consumable generating the profits.

${ }^{13}$ Porter (1980) argued that firms may opt for a focus strategy, which may be cost- or differentiation-based, and which may target a segment. A niche strategy differs from a focus strategy in the following ways: a niche strategy is based on differentiation, not cost; a niche is typically smaller than a segment (Dalgic \& Leeuw, 1994); a niche seller has more market power than one implementing a focus strategy (Merrilees \& Tiessen, 1999).

${ }^{14}$ This is supported by Dow's (2017) finding that the absolute number of customers in the firm's home market has a significantly negative impact on the probability of a firm being a BG.

${ }^{15}$ Atlassian, an Australian BG software seller, never even rented a booth at a convention. The only advertising it did in its early days was to give away free bottles of beer - with an Atlassian label replacing the original one - at programmer conventions like Java One, and to send T-shirts to customers of the high-priced version of its software (Littlewood, 2011).

${ }^{16}$ Innovative projects by Interna include the CitizenM hotel at Schiphol Airport, the BMW Welt museum in Munich, and the renovation of the Grand Hotel Villa Feltrinelli on Lake Garda. 
${ }^{17}$ As argued above, we can dismiss two other explanations put forth by IE scholars, namely that BGs result from improvements in communication and transportation and that their founders are characterized by a high international orientation, global vision, entrepreneurial orientation, and so forth. It is unclear why communication and transportation improvements have only benefited some firms, but not others. As we have shown, founder orientations are measured ex post, thus leading to a tautological relationship.

${ }^{18}$ Working in an MNE may have taught BG entrepreneurs to deal with people from other countries (Zucchella et al. 2007).

${ }^{19}$ Italian industrial districts are geographical areas with a concentration of firms specializing in a particular product.

\section{REFERENCES}

Acs, Z., Morck, R., Shaver, M., \& Yeung, B. 1997. The internationalization of small and medium sized enterprises: $A$ policy perspective. Small Business Economics, 9(1): 7-20.

Al-Laham, A., \& Souitaris, V. 2008. Network embeddedness and new-venture internationalization: Analyzing international linkages in the German biotech industry. Journal of Business Venturing, 23(5): 567-586.

Allison, P. D. 1984. Event history analysis: Regression for longitudinal data. Newbury Park: Sage.

Andersson, S. 2006. International growth strategies in consumer and business-to-business markets in manufacturing and service sectors. Journal of Euromarketing, 15(4): 35-56.

Andersson, S., Gabrielsson, J., \& Wictor, I. 2004. International activities of small firms: economic factors influencing the internationalization and export growth of small firms. Canadian Journal of Administrative Science, 21(1): 22-34.

Andersson, S., Evers, N., \& Griot, C. 2013. Local and international networks in small firm internationalization: Cases from the Rhône-Alpes medical technology regional cluster. Entrepreneurship and Regional Development, 25(9-10): 867-888.

Armstrong, J., \& Overton, T. 1977. Estimating non-response bias in mail surveys. Journal of Marketing Research, 14(3): 396-402.

Arregle, J.-L., Naldi, L., Nordqvist, M., \& Hitt, M. 2012. Internationalization of family-controlled firms: a study of external involvement in governance. Entrepreneurship Theory and Practice, 36(6): 1115-1143.

Asemokha, A., Musona, J., Torkelli, L., \& Saarenketo, S. 2019. Business model innovation and entrepreneurial orientation relationships in SMEs: Implications for international performance. Journal of International Entrepreneurship, 17(3): 425-453.

Autio, E. 2005. Creative tension: the significance of Ben Oviatt's and Patricia McDougall article 'towards a theory of international new ventures. Journal of International Business Studies, 36(1): 9-19.

Autio, E. 2017. Strategic entrepreneurial internationalization: A normative framework. Strategic Entrepreneurial Journal, 11(3): 211-227.

Autio, E., Sapienza, H., \& Almeida, J. 2000. Effects of age at entry, knowledge intensity, and imitability on international growth. Academy of Management Journal, 43(5): 909-1014.
${ }^{20} \mathrm{An}$ alternative way to measure the experience of the members of the entrepreneurial team is to take the sum of the experience of team members. If, for instance the firm is led by three entrepreneurs, one with three years of international experience and the other two with one year, then the international experience of the entrepreneurial team is five. Using this alternative measure of experience did not change our results.

${ }^{21}$ The ratio varies from $1 \%$ for Calabria in the south to $37 \%$ for Friuli Venezia Giulia in the north.

${ }^{22}$ Results are available from the authors.

${ }^{23}$ We thank an anonymous reviewer for suggesting this test. Results are available from the authors.

Baden-Fuller, C., \& Morgan, M. 2010. Business models as models. Long Range Planning, 43(2-3): 156-171.

Bartlett, C. \& George, A. 1998. Acer America: Development of the Aspire. Harvard Business School case 9-399-011.

Basile, R., Giunta, A., \& Nugent, J. 2003. Foreign expansion by Italian manufacturing firms in the nineties: An ordered probit analysis. Review of Industrial Organization, 23(1): 1-24.

Bell, J. 1995. The internationalization of small computer software firms: A further challenge to "stage" theories. European Journal of Marketing, 29(8): 60-75.

Bell, J., McNaughton, R., Young, S., \& Crick, D. 2003. Towards an integrative model of small firm internationalization. Journal of International Entrepreneurship, 1(4): 339-362.

Bernard, A., \& Jensen, J. 2004. Why some firms export. Review of Economics and Statistics, 86(2): 561-569.

Bettman, J., \& Weitz, B. 1985. Attributions in the board room: Causal reasoning in corporate annual reports. Administrative Science Quarterly, 28(2): 165-183.

Bilkey, W. J., \& Tesar, G. 1977. The export behavior of smallersized Wisconsin manufacturing firms. Journal of International Business Studies, 8(1): 93-98.

Bohnsack, R., Ciulli, F., \& Kolk, A. 2020. The role of business models in firm internationalization: An exploration of European electricity firms in the context of the energy transition. Journal of International Business Studies. https://doi.org/10. 1057/s41267-020-00364-4.

Bortoluzzi, G., \& Tracogna, A. 2013. Imprenditori che sfidano la crisi. Dati ed esperienze dal Friuli Venezia Giuli. Milan: Franco Angeli.

Brown, P. \& Bell J. 2001. Industrial clusters and small firm internationalisation. In J. H. Taggart, M Berry \& M. McDermott (Eds.), Multinationals in a New Era: 10-26. Academy of International Business, UK Chapter.

Cachon, G. 2020. A research framework for business models: What is common among fast fashion, e-tailing, and ride sharing? Management Science, 66(3): 1172-1192.

Cannone, G., \& Ughetto, E. 2014. Born Globals: A cross-country survey on high-tech start-ups. International Business Review, 23(1): 272-283.

Cavusgil, S. T., \& Knight, G. 2015. The born global firm: An entrepreneurial and capabilities perspective on early and rapid 
internationalization. Journal of International Business Studies, 46(1): 3-16.

Cerrato, D., \& Piva, M. 2012. The internationalization of small and medium-sized enterprises: The effect of family management, human capital and foreign ownership. Journal of Management \& Governance, 16(4): 617-644.

Chandra, Y., Styles, C., \& Wilkinson, I. 2009. The recognition of first time international entrepreneurial opportunities: Evidence from firms in knowledge-based industries. International Marketing Review, 26(1): 30-61.

Chang, S.-J., van Witteloostuijn, A., \& Eden, L. 2010. From the editors: Common method variance in international business research. Journal of International Business Studies, 41(2): 178-184.

Child, J., Hsieh, L., Elbanna, S., Kamowska, J., Marinova, S., Puthusserry, P., Tsai, T., Narooz, R., \& Zhang, Y. 2017. SME international business models: The role of context and experience. Journal of World Business, 52(5): 664-679.

Chetty, S., \& Campbell-Hunt, C. 2004. A strategic approach to internationalization: A traditional versus a "born global" approach. Journal of International Marketing, 12(1): 57-81.

Ciravegna, L., Kuivalainen, O., Kundu, S., \& Lopez, L. 2018. The antecedents of early internationalization: A configurational perspective. Journal of World Business, 27(6): 1200-1212.

Coviello, N. 2006. The network dynamics in the international new venture. Journal of International Business Studies, 37(5): 713-731.

Coviello, N. 2015. Re-thinking research on born globals. Journal of International Business Studies, 46(1): 17-26.

Coviello, N., \& Munro, H. 1997. Network relationships and the internationalization process of small software firms. International Business Review, 6(4): 61-386.

Cox, D. 1992. Regression models and life-tables. In S. Kotz, \& N. Johnson (Eds.), Breakthroughs in statistics, 527-541. New York: Springer.

Crick, D., \& Spence, M. 2005. The internationalisation of 'high performing' UK high-tech SMEs: A study of planned and unplanned strategies. International Business Review, 14(2): 167-185.

Dalgic, T., \& Leeuw, M. 1994. Niche marketing revisited: Concept, applications and some European cases. European Journal of Marketing, 28(4): 39-55.

D’Angelo, A., Majocchi, A., \& Buck, T. 2016. External managers, family ownership and the scope of SME internationalization. Journal of World Business, 51(4): 534-547.

Dib, L. A., da Rocha, A., \& Ferreira da Silva, J. 2010. The internationalization process of Brazilian software firms and the born global phenomenon: Examining firm, network, and entrepreneur variables. Journal of International Entrepreneurship, 8(3): 233-253.

Dow, D. 2017. Born Global and accidental internationalists: Has Hennart (2014) opened a can of worms? Review of International Business and Strategy, 27(3): 286-307.

Dunning, J. 1988. The theory of international production. International Trade Journal, 3(1): 21-66.

Ellis, P. 2011. Social ties and international entrepreneurship: Opportunities and constraints affecting firm internationalization. Journal of International Business Studies, 42(1): 99-127.

Ellis, P., \& Pecotich, A. 2001. Social factors influencing export initiation in small and medium-sized enterprises. Journal of Marketing Research, 38(1): 119-130.

Evers, N. 2010. Factors influencing the internationalisation of new ventures in the Irish aquaculture industry: An exploratory study. Journal of International Entrepreneurship, 8(4): 392-416.

Evers, N. 2011. International new ventures in "low tech" sectors: A dynamic capabilities perspective. Journal of Small Business and Enterprise Development, 18(3): 502-528.

Falay, Z., Salimaki, M., Ainamo, A., \& Gabrielsson, M. 2010. Design-intensive Born Globals: A multiple case study of marketing management. Journal of Marketing Management, 23(9-10): 877-899.

Fan, T., \& Phan, P. 2007. International new ventures: Revisiting the influences behind the born-global firm. Journal of International Business Studies, 38(7): 1113-1131.

Fernhaber, S., McDougall-Covin, P., \& Shepherd, D. 2009. International entrepreneurship: Leveraging internal and external knowledge sources. Strategic Entrepreneurship Journal, 3(4): 297-320.

Fernhaber, S., \& Li, D. 2013. International exposure through network relationships: Implications for new venture internationalization. Journal of Business Venturing, 28(2): 316-334.

Fjelstad, O., \& Snow, C. 2018. Business model and organization design. Long Range Planning, 51(1): 32-39.

Gerschewski, S., Rose, E., \& Lindsay, V. 2015. Understanding the drivers of international performance for Born Global firms: An integrated perspective. Journal of World Business, 50(3): 558-575.

Giachetti, C. 2018. Smartphone start-ups: Navigating the iPhone revolution. Cham: Palgrave Macmillan.

Given, J. 2017. Born global, made local: Multinational enterprise and the Australian early wireless industry. Australian Economic History Review, 57(2): 158-193.

Golovko, E., \& Valentini, G. 2011. Exploring the complementarity between innovation and export for SMEs' growth. Journal of International Business Studies, 42(3): 362-380.

Guercini, S., \& Milanesi, M. 2017. Extreme luxury fashion: Business model and internationalization process. International Marketing Review, 34(3): 403-424.

Hagen, B., \& Zucchella, A. 2014. Born Global or Born to Run? The long-term growth of Born Global firms. Management International Review, 54(4): 497-525.

Hair, J., Anderson, R., Tatham, R., \& William, C. 1995. Multivariate data analysis. Englewood Cliffs: Prentice Hall.

Hennart, J.-F. 2009. Down with MNE-centric theories: Market entry and expansion as the bundling of MNE and local assets. Journal of International Business Studies, 40(7): 1432-1454.

Hennart, J.-F. 2014. The accidental internationalists: A theory of Born Globals. Entrepreneurship Theory and Practice, 38(1): 117-135.

Hennart, J-F., Kim, D.-J. \& Zeng, M. 1998. The impact of joint venture status on the longevity of Japanese stakes in U.S manufacturing affiliates. Organization Science, 9(3): 382-395.

Herbig, P., Howard, C., \& Kramer, H. 1995. The installed base effect: Implications for the management of innovations. Journal of Marketing Management, 11(5): 387-401.

Hymer, S. 1976. The international operations of national firms: $A$ study of foreign direct investment. Cambridge, Mass: MIT Press. Interna. 2020. Projects. www.interna.it/en/projects/prj.php. Accessed 6 November 2020.

ISTAT. 2015a. I distretti industriali 2011. $9^{\circ}$ Censimento dell'industria e dei servizi e Censimento delle istituzioni non profit. Rome: ISTAT. Available at https://www.istat.it/it/archivio/ 172446

ISTAT. 2015b. Serie storiche: sezione Industria e Servizi. Commercio estero. http://seriestoriche.istat.it/index.php. Accessed 27 April 2015.

Jantunen, A., Nummela, N., Puumalainen, K., \& Saarenketo, S. 2008. Strategic orientations of born globals-do they really matter? Journal of World Business, 43(2): 158-170.

Johanson, J., \& Vahlne, J. 1977. The internationalization process of the firm-a model of knowledge development and increasing foreign market commitment. Journal of International Business Studies, 8(1): 23-32.

Johanson, J., \& Vahlne, J. 1990. The mechanism of internationalization. International Marketing Review, 7(4): 11-24.

Johanson, J., \& Vahlne, J. E. 2009. The Uppsala internationalization process model revisited: From liability of foreignness to 
liability of outsidership. Journal of International Business Studies, 40(9): 1411-1431.

Johanson, J., \& Wiedersheim-Paul, F. 1975. The internationalization of the firm: Four Swedish cases. Journal of Management Studies, 12(3): 305-322.

Knight, G., \& Cavusgil, S. 1996. The born global firm: A challenge to traditional internationalization theory. Advances in International Marketing, 8(8): 11-26.

Knight, G., \& Cavusgil, S. 2004. Innovation, organizational capabilities, and the born global firm. Journal of International Business Studies, 35(2): 124-141.

Knight, G., \& Liesch, P. 2016. Internationalization: from incremental to born global. Journal of World Business, 51(1): 93-102.

Kotler, P. 2003. Marketing management (11th ed.), Upper Saddle River, NJ: Prentice Hall.

Kuivalainen, O., Saarenketo, S., \& Puumalainen, K. 2012. Startup patterns of internationalization: A framework and its application in the context of knowledge-intensive SMEs. European Management Journal, 30(4): 372-385.

Kuivalainen, O., Sundqvist, S., \& Servais, P. 2007. Firms' degree of born-globalness, international entrepreneurship orientation and export performance. Journal of World Business, 43(2): 253-267.

Leonidou, L. 2004. An analysis of the barriers hindering small business export development. Journal of Small Business Management, 42(3): 279-302.

Leonidou, L., \& Katsikeas, C. 1996. The export development process: An integrative review of empirical models. Journal of International Business Studies, 27(3): 517-551.

Littlewood, M. 2011. From \$0-100 million with no sales people: the Atlassian 10 commandments for startups (transcript of presentation of Scott Farquhar at the 2011 Business of Software conference). BofS Insights, 15 September 2011. http://businessofsoftware.org/2011/09/from-0-100-millionwith-no-sales-people-the-atlassian-10-commandments-forstartups. Accessed 12 February 2018.

Liu, X., Xiao, W., \& Huang, X. 2008. Bounded entrepreneurship and internationalization of indigenous private-owned firms. International Business Review, 17(4): 488-508.

Loane S., \& Bell J. 2006. Rapid internationalisation among entrepreneurial firms in Australia, Canada, Ireland and New Zealand. An extension to the network approach. International Marketing Review, 23 (5): 467-485.

Lopez, L., Kundu, S., \& Ciravegna, L. 2009. Born global or born regional? Evidence from an exploratory study of the Costa Rica software industry. Journal of International Business Studies, 40(7): 1228-1238.

Love, I., \& Roper, S. 1999. The determinants of innovation: $R \& D$, technology transfer and networking effects. Review of Industrial Organization, 15(1): 43-64.

Madsen, T. G., \& Servais, P. 1997. The internationalization of born globals: An evolutionary process? International Business Review, 6(6): 561-583.

Magretta, J. 2002. Why business models matter. Harvard Business Review, 80(May): 86-92.

Majocchi, A., D'Angelo, A., Forlani, E., \& Buck, T. 2018. Bifurcation bias and exporting: Can foreign work experience be an answer? Insight from European family SMEs. Journal of World Business, 53(2): 237-247.

Massa, L., \& Tucci, C. 2013. Business model innovation. In M. Dodgson, D. Gann, \& N. Phillips (Eds.), Oxford handbook of innovation management: 420-439. Oxford: Oxford University Press.

Mata, J., \& Portugal, P. 2000. Closure and divestiture by foreign entrants: the impact of entry and post-entry strategies. Strategic Management Journal, 21(5): 549-562.
Mazucca, A. 2006. La fabbrica virtuale arreda grand hotel e yacht. // Giornale, 25 March. http://www.interna.it/it/pressreview/prs.php. Accessed 5 November 2020.

McDougall, P. 'ं. ., Oviatt, B. M., \& Shrader, R. C. 2003. Comparison of international and domestic new ventures. Journal of International Entrepreneurship, 1(1): 59-82.

Mellahi, K. \& Wilkinson, A. 2004. Organizational failure: a critique of recent research and a proposed integrative framework. International Journal of Management Reviews, 5/6(1): 21-41.

Merrilees, B., \& Tiessen, J. 1999. Building generalizable SME international marketing models using case studies. International Marketing Review, 16(4/5): 326-344.

Messati, E. 2006. La sfida di Derna e Diego: codice etico e albergo di lusso, così conquistiamo i VIP. II Messaggero, 15 October, http://www.interna.it/it/press-review/prs.php. Accessed 5 November 2020.

Miller, D., \& Ross, M. 1975. Self-serving biases in attribution of causality: Fact or fiction? Psychological Bulletin, 82(2): 213-225.

Moen, O. 2002. The born globals: A new generation of small European exporters. International Marketing Review, 19(2): 156-175.

Mort, G., \& Weerawardena, J. 2006. Networking capability and international entrepreneurship: How networks function in Australian Born Global firms. International Marketing Review, 23(5): 549-572.

Naudé, W. 2009. "Rushing in where angels fear to tread"? The early internationalization of indigenous Chinese firms. Journal of Chinese Economic and Foreign Trade Studies, 2(3): 163-177.

Nummela, N., Saarenketo, S., \& Puumalainen, K. 2004a. Rapidly with a rifle or more slowly with a shotgun? Searching the company boundaries of internationalizing ITC firms. Journal of International Entrepreneurship, 2(4): 275-288.

Nummela, N., Saarenketo, S., \& Puumalainen, K. 2004b. A global mindset: A prerequisite for successful internationalization? Canadian Journal of Administrative Science, 21(1): 51-64.

Ojala, A., \& Tyrväinen, P. 2006. Business models and market entry mode choice of small software firms. Journal of International Entrepreneurship, 4(2/3): 69-81.

Onetti, A., Zucchella, A., Jones, M., \& McDougall-Covin, P. 2012. Internationalization, innovation, and entrepreneurship: Business models for new technology-based firms. Journal of Management and Governance, 16(3): 337-368.

Osiyesvskyy, O., Troshkova, M., \& Bao, Y. 2017. What makes a global business model? In A. Presenza, \& L. Sheehan (Eds.), Geopolitics and strategic management in the global economy: 19-39. Hershey, PA: IGI Global.

Osterwalder, A., \& Pigneur, Y. 2010. Business model generation. Hoboken, NJ: Wiley.

Oviatt, B., \& McDougall, P. 1994. Towards a theory of international new ventures. Journal of International Business Studies, 25(1): 45-64.

Petersen, B., \& Pedersen, T. 1997. Twenty years after: support and critique of the Uppsala internationalization model. In I. Bjorkman, \& M. Forsgren (Eds.), The nature of the transnational firm: 117-134. Copenhagen: Copenhagen Business School Press.

Pitelis, C., \& Verbeke, A. 2007. Edith Penrose and the future of the multinational enterprise: New research directions. Management International Review, 47(2): 139-149.

Porter, M. 1980. Competitive strategy. New York: Free Press.

Prashantham, S., Dhanaraj, C., \& Kumar, K. 2015. Ties that bind: Ethnic ties and new venture internationalization. Long Range Planning, 48(5): 317-333.

Rask, M. 2014. Internationalization through business model innovation: in search of relevant design dimensions and elements. Journal of International Entrepreneurship, 12(2): 146-161. 
Rasmussen, E., Madsen, T. K., \& Evangelista, F. 2001. The founding of the born global company in Denmark and Australia: Sensemaking and networking. Asia Pacific Journal of Marketing and Logistics, 13(3): 75-107.

Rennie, M. 1993. Global competitiveness: Born global. McKinsey Quarterly, 4: 45-52.

Reuber, A. R., \& Fischer, E. 1997. The influence on the management team's international experience on the internationalization behaviors of SMEs. Journal of International Business Studies, 28(4): 807-825.

Rialp, A., Rialp, J., \& Knight, G. 2005. The phenomenon of early internationalizing firms: What do we know after a decade (1993-2003) of scientific inquiry? International Business Review, 14(2): 147-166.

Ritter, T., \& Lettl, C. 2018. The wider implications of businessmodel research. Long Range Planning, 51(1): 1-8.

Rugman, A. 1981. Inside the multinationals: the economics of internal markets. Columbia: Columbia University Press.

Rugman, A., \& Verbeke, A. 2001. Subsidiary-specific advantages in multinational enterprises. Strategic Management Journal, 22(3): 237-250.

Rugman, A., Verbeke, A., \& Nguyen, T. K. 2011. Fifty years of international business theory and beyond. Management International Review, 51(6): 755-786.

Schilke, O., Reimann, M., \& Thomas, J. 2009. When does international marketing standardization matter to firm performance? Journal of International Marketing, 17(4): 24-46.

Sharma, D., \& Blomstermo, A. 2003. The internationalization process of born globals: A network view. International Business Review, 12(6): 657-788.

Sleuwaegen, L., \& Onkelinx, J. 2014. International commitment, post-entry growth and survival of international new ventures. Journal of Business Venturing, 29(1): 106-120.

Sterlacchini, A. 1999. Do innovative activities matter to small firms in non-R\&D-intensive industries? An application to export performance. Research Policy, 28(8): 819-832.

Sui, S., \& Baum, M. 2014. Internationalization strategy, firm resources and the survival of SMEs in the export market. Journal of International Business Studies, 45(7): 821-841.

Sullivan Mort, G., Weerawardena, I., \& Liesch, P. 2012. Advancing entrepreneurial marketing: Evidence from born global firms. European Journal of Marketing, 46(3/4): 542-561.

Teece, D. 1986. Profiting from technological innovations: implications for integration, collaboration, licensing, and public policy. Research Policy, 15(6): 285-305.

Teece, D. 2010. Business model, business strategy and innovation. Long Range Planning, 42(2-3): 172-194.

Toften, K., \& Hammervoll, T. 2010. Strategic orientation of niche firms. Journal of Research in Marketing and Entrepreneurship, 12(2): 108-121.

Vahlne, J.-E., \& Johanson, J. 2017. From internationalization to evolution: The Uppsala model at 40 years. Journal of International Business Studies, 48(9): 1087-1102.

Verbeke, A. 2009. International business strategy. Cambridge: Cambridge University Press.

Verbeke, A., \& Ciravegna, L. 2018. International entrepreneurship research versus international business research: A false dichotomy? Journal of International Business Studies, 49(4): 387-394.

Verbeke, A., Coeurderoy, R., \& Matt, T. 2018. The future of international business research on corporate globalization that never was. Journal of International Business Studies, 49(9): 1101-1112.

Verbeke, A., \& Kano, L. 2015. The new internalization theory and multinational enterprises from emerging economies: A business history perspective. Business History Review, 89(3): 415-445.
Verbeke, A., Zargarzadeh, M., \& Osiyevskyy, O. 2014. Internalization theory, entrepreneurship, and international new ventures. Multinational Business Review, 22(3): 246-269.

Vissak, T., Zhang, X., \& Ukrainski, K. 2012. Successful born globals without experiential market knowledge: survey evidence from China. In P. Gabrielsson, \& V. Kirpalani (Eds.), Handbook of research on Born Globals: 353-379. Cheltenham: Edward Elgar.

Weerawardena, J., Mort, G. S., Liesch, P. W., \& Knight, G. 2007. Conceptualizing accelerated internationalization in the born global firm: A dynamic capabilities perspective. Journal of World Business, 42(3): 294-306.

Westhead, P., Wright, M., \& Ucbasaran, D. 2001. The internationalization of new and small firms: A resource-based view. Journal of Business Venturing, 16(4): 333-358.

Wickramasekera, R., \& Bamberry, G. 2003. Exploration of born globals/international new ventures: Some evidence from the Australian wine industry. Australasian Journal of Regional Studies, 9(2): 207-220.

Yu, J., Gilbert, B., \& Oviatt, B. 2011. Effects of alliances, time, and network cohesion on the initiation of foreign sales by new ventures. Strategic Management Journal, 32(4): 424-446.

Zaheer, S. 1995. Overcoming the liability of foreignness. Academy of Management Journal, 38(2): 341-363.

Zaheer, S., \& Mosakowski, E. 1997. The dynamics of the liability of foreignness: A global study of survival in financial services. Strategic Management Journal, 18(6): 439-464.

Zhang, M., Tansuhaj, P., \& McCullough, J. 2009. International entrepreneurial capability: the measurement and a comparison between born global firms and traditional exporters in China. Journal of International Entrepreneurship, 7(4): 292-322.

Zott, C., Amit, R., \& Massa, L. 2011. The business model: recent developments and future research. Journal of Management, 37(4): 1019-1042.

Zucchella, A., Palamara, G., \& Denicolai, S. 2007. The drivers of the early internationalization of the firm. Journal of World Business, 42(3): 268-280.

Zucchella, A., Hagen, B., Denicolai, S., \& Masucci, M. 2016. Early and accelerated internationalization: The role of the niche strategy in a new generation of exporters. International Journal of Export Marketing, 1(1): 27-47.

\section{ABOUT THE AUTHORS}

Jean-François Hennart is Professor of International Management emeritus at Tilburg University and visiting professor at Politecnico di Milano and Aalborg University. His 1982 book, A Theory of Multinational Enterprise, pioneered the application of transaction cost theory (TCT) to international business. He has continued to apply TCT to multinational enterprises from developed and emerging countries, family firms, born globals, and modes of foreign market entry. His publications have garnered more than 18,000 Google citations.

Antonio Majocchi is a full-time Professor of International Business at the Luiss Guido Carli University in Rome, Italy. His research focuses on the theory of MNCs, firm internationalization 
strategies, and the impact of corporate governance on these strategies. He has held visiting positions at Northeastern University, the University of Valencia, and Fribourg University.

Birgit Hagen is Associate Professor of International Entrepreneurship and Marketing at the University of Pavia, Italy. Her research focuses on SME internationalization, in particular the entrepreneurial behavior underlying internationalization. Before she joined the University of Pavia, Birgit worked for a multinational enterprise in Vienna, Paris, and Milan.
Open Access This article is licensed under a Creative Commons Attribution 4.0 International License, which permits use, sharing, adaptation, distribution and reproduction in any medium or format, as long as you give appropriate credit to the original author(s) and the source, provide a link to the Creative Commons licence, and indicate if changes were made. The images or other third party material in this article are included in the article's Creative Commons licence, unless indicated otherwise in a credit line to the material. If material is not included in the article's Creative Commons licence and your intended use is not permitted by statutory regulation or exceeds the permitted use, you will need to obtain permission directly from the copyright holder. To view a copy of this licence, visit http://creativecommons.org/licenses/by/4.0/.

Publisher's Note Springer Nature remains neutral with regard to jurisdictional claims in published maps and institutional affiliations.

Accepted by Alain Verbeke, Editor-in-Chief, 7 March 2021. This article has been with the authors for four revisions. 